\title{
Valency-Based Descriptors for Silicon Carbides, Bismuth(III) Iodide, and Dendrimers in Drug Applications
}

\author{
Qi-Zhao Li, ${ }^{1}$ Abaid ur Rehman Virk (i), ${ }^{2}$ Kashif Nazar, ${ }^{3}$ Imran Ahmed (D), ${ }^{3}$ \\ and Iskander Tlili $\mathbb{D}^{4,5}$ \\ ${ }^{1}$ School of Pharmacy, Anhui Xinhua University, Hefei 230088, China \\ ${ }^{2}$ Department of Mathematics, University of Management and Technology, Lahore 54000, Pakistan \\ ${ }^{3}$ Department of Mathematics, COMSATS University of Islamabad, Lahore Campus, Lahore 54000, Pakistan \\ ${ }^{4}$ Department for Management of Science and Technology Development, Ton Duc Thang University, Ho Chi Minh City, Vietnam \\ ${ }^{5}$ Faculty of Applied Sciences, Ton Duc Thang University, Ho Chi Minh City, Vietnam \\ Correspondence should be addressed to Iskander Tlili; iskander.tlili@tdtu.edu.vn
}

Received 20 October 2019; Revised 3 December 2019; Accepted 18 December 2019; Published 28 May 2020

Guest Editor: Shaohui Wang

Copyright ( 2020 Qi-Zhao Li et al. This is an open access article distributed under the Creative Commons Attribution License, which permits unrestricted use, distribution, and reproduction in any medium, provided the original work is properly cited.

\begin{abstract}
Silicon carbide $(\mathrm{SiC})$, also called carborundum, is a semiconductor containing silicon and carbon. Dendrimers are repetitively branched molecules that are typically symmetric around the core and often adopt a spherical three-dimensional morphology. Bismuth(III) iodide is an inorganic compound with the formula $\mathrm{BiI}_{3}$. This gray-black solid is the product of the reaction between bismuth and iodine, which once was of interest in qualitative inorganic analysis. In chemical graph theory, we associate a graph to a compound and compute topological indices that help us in guessing properties of the understudy compound. A topological index is the graph invariant number, calculated from a graph representing a molecule. Most of the proposed topological indices are related either to a vertex adjacency relationship (atom-atom connectivity) in the graph or to topological distances in the graph. In this paper, we aim to compute the first and second Gourava indices and hyper-Gourava indices for silicon carbides, bismuth(III) iodide, and dendrimers.
\end{abstract}

\section{Introduction}

Mathematical chemistry provides tools such as polynomials and functions that depend upon the information hidden in the symmetry of graphs of chemical compounds and helps to predict properties of the understudy molecular compound without the use of quantum mechanics. A topological index is a numerical parameter of a graph and depicts its topology. It describes the structure of molecules numerically and are used in the development of qualitative structure activity relationships (QSARs). There are three kinds of topological indices, namely, degree-based, distance-based, and surfacebased topological indices. Lot of research has been done on degree-based topological indices, for example, see [1-9]. Degree-based topological indices correlate the structure of the molecular compound with its various physical properties, biological activities, and chemical reactivity [10-14].
Boiling point, heat of formation, fracture toughness, strain energy, and rigidity of a molecule are strongly connected to its graphical structure.

The first topological index was introduced by Wiener when he was studying the boiling point of alkanes [15], which is now known as the Wiener index [16-20]. In 1975, Milan Randić introduced a simple topological index called the Randić index [21]. Many research papers and survey papers have been written on this graph invariant due to its interesting mathematical properties and valuable applications in chemistry [22-27]. The other oldest topological indices are Zagreb indices defined by Gutman and Trinajstic in [28] and are one of the most studied topological indices [29-33]. Topological indices are helpful in guessing properties of concerned compounds and are used in QSPRs [34-37]. There are more than 148 topological indices in the literature [38-42], but none of them are able to guess all the 
properties of the concerned compound (together they do it to some extent). Therefore, there is always room to define new topological indices [43]. Recently, in 2017, the first and second Gourava indices [44] were defined as

$$
\begin{aligned}
& \mathrm{GO}_{1}(G)=\sum_{u v \in E(G)}\left[\left(d_{u}+d_{v}\right)+\left(d_{u} \cdot d_{v}\right)\right], \\
& \mathrm{GO}_{2}(G)=\sum_{u v \in E(G)}\left[\left(d_{u}+d_{v}\right) \cdot\left(d_{u} \cdot d_{v}\right)\right] .
\end{aligned}
$$

In the same year, the first and second hyper-Gourava indices [45] have been defined as

$$
\begin{aligned}
& \operatorname{HGO}_{1}(G)=\sum_{u v \in E(G)}\left[\left(d_{u}+d_{v}\right)+\left(d_{u} \cdot d_{v}\right)\right]^{2}, \\
& \operatorname{HGO}_{2}(G)=\sum_{u v \in E(G)}\left[\left(d_{u}+d_{v}\right) \cdot\left(d_{u} \cdot d_{v}\right)\right]^{2} .
\end{aligned}
$$

Note that $\mathrm{GO}_{1}(G)=M_{1}(G)+M_{2}(G), \quad \mathrm{GO}_{2}(G)=$ $M_{1}(G) M_{2}(G), \quad \operatorname{HGO}_{1}(G)=H_{1}(G)+H_{2}(G)+2 M_{1}(G)+$ $M_{2}(G)$, and $\operatorname{HGO}_{2}(G)=H_{1}(G) H_{2}(G)$. In this paper, the aim is to compute Gourava indices and hyper-Gourava indices for silicone carbides, bismuth triiodide, and dendrimers and their graphical representations.

\section{Methodology}

To compute our results, first we constructed the graph of the concerned molecular compounds and counted the total number of vertices and edges. Secondly, we divided the edge set of concerned graphs into different classes based on the degrees of end vertices. By applying definitions of Gourava indices, we computed our desired results. We plotted our computed results by using Maple 2015 to see their dependencies on the involved parameters.

\section{Gourava Indices}

In this section, we present our main computational results. This section consists of three subsections. In Section 3.1, we present results about silicone carbides $\mathrm{Si}_{2} \mathrm{C}_{3}-\mathrm{I}[p, q]$, $\mathrm{Si}_{2} \mathrm{C}_{3}-\mathrm{II}[p, q], \mathrm{Si}_{2} \mathrm{C}_{3}-\mathrm{III}[p, q]$, and $\mathrm{SiC}_{3}-\mathrm{III}[p, q]$. In Section 3.2, we give results about the bismuth triiodide chain $m-\mathrm{BiI}_{3}$ and the bismuth triiodide sheet $\mathrm{BiI}_{3}(m \times n)$. In Section 3.3, we present results about four dendrimer structures: porphyrin dendrimer $\mathrm{D}_{n} \mathrm{P}_{n}$, propyl ether imine dendrimer (PETIM), zinc-porphyrin dendrimer $\mathrm{DPZ}_{n}$, and Poly(EThyleneAmidoAmine) dendrimer (PETAA).

3.1. Gourava Indices for Silicon Carbides. Silicon carbide ( $\mathrm{SiC})$, also called carborundum, is a semiconductor containing silicon and carbon. It occurs in nature as the incredibly uncommon mineral Moissanite. Manufactured $\mathrm{SiC}$ powder has been created in mass since 1893 for use as an abrasive. Grains of silicon carbide are reinforced together by sintering to shape extremely hard ceramic production that are generally utilized in applications requiring high continuance, for example, vehicle brakes, vehicle clutches, and ceramic plates in impenetrable vests. Electronic utilizations of silicon carbide, for example, light-emitting diodes (LEDs) and locators in early radios, were first exhibited around 1907. SiC is utilized in semiconductor electronic devices that work at high temperatures or high voltages, or both. Huge single crystals of silicon carbide can be developed by the Lely technique, and they can be cut into gems known as manufactured Moissanite. SiC with a high surface zone can be created from $\mathrm{SiO}_{2}$ contained in the plant material. Due to huge amount of application, silicone carbides have been studied extensively $[6,42]$. In this section, we computed Gourava indices for silicon carbides $\mathrm{Si}_{2} \mathrm{C}_{3}-\mathrm{I}[p, q]$, $\mathrm{Si}_{2} \mathrm{C}_{3}-\mathrm{II}[p, q], \mathrm{Si}_{2} \mathrm{C}_{3}-\mathrm{III}[p, q]$, and $\mathrm{SiC}_{3}-\mathrm{III}[p, q]$.

3.1.1. Gourava Indices for Silicon Carbide $\mathrm{Si}_{2} \mathrm{C}_{3}-I[p, q]$. The molecular graphs of silicon carbide $\mathrm{Si}_{2} \mathrm{C}_{3}-\mathrm{I}[p, q]$ are shown in Figures 1-4, where Figure 1 shows the unit cell of silicone carbide, Figure 2 shows $\mathrm{Si}_{2} \mathrm{C}_{3} \mathrm{I}[p, q]$ for $p=4, q=3$, Figure 3 shows $\mathrm{Si}_{2} \mathrm{C}_{3} \mathrm{I}[p, q]$ for $p=4, q=1$, and Figure 4 shows $\mathrm{Si}_{2} \mathrm{C}_{3} \mathrm{I}[p, q]$ for $p=4, q=3$. The edge partition of the edge set of $\mathrm{Si}_{2} \mathrm{C}_{3}-\mathrm{I}[p, q]$ based on the degree of the end vertex is given in Table 1 .

Theorem 1. Let $G$ be the graph of silicon carbide $\mathrm{Si}_{2} \mathrm{C}_{3} I[p, q]$. Then, the first and second Gourava indices are
(1) $G O_{1}(G)=225 p q-61 p-91 q+18$,
(2) $\mathrm{GO}_{2}(G)=810 p q-290 p-430 q+126$.

Proof. From the edge partition of $\mathrm{Si}_{2} \mathrm{C}_{3} \mathrm{I}[p, q]$ given in Table 1, we have

(1) The first Gourava index for $\mathrm{Si}_{2} \mathrm{C}_{3} \mathrm{I}[p, q]$ is

$$
\begin{aligned}
\mathrm{GO}_{1}(G)= & \sum_{u v \in E(G)}\left[\left(d_{u}+d_{v}\right)+\left(d_{u} \cdot d_{v}\right)\right] \\
= & {[(1+2)+(1 \times 2)](1)+[(1+3)+(1 \times 3)](1) } \\
& +[(2+2)+(2 \times 2)](p+2 q) \\
& +[(2+3)+(2 \times 3)](6 p+8 q-9) \\
& +[(3+3)+(3 \times 3)](15 p q-9 p-13 q+7) \\
= & 225 p q-61 p-91 q+18 .
\end{aligned}
$$

(2) The second Gourava index for $\mathrm{Si}_{2} \mathrm{C}_{3} \mathrm{I}[p, q]$ is

$$
\begin{aligned}
\mathrm{GO}_{2}(G)= & \sum_{u v \in E(G)}\left[\left(d_{u}+d_{v}\right) \cdot\left(d_{u} \cdot d_{v}\right)\right] \\
= & {[(1+2) \times(1+2)](1)+[(1+3) \times(1+3)](1) } \\
& +[(2+2) \times(2+2)](p+2 q) \\
& +[(2+3) \times(2 \times 3)](6 p+8 q-9) \\
& +[(3+3) \times(3+3)](15 p q-9 p-13 q+7) \\
= & 810 p q-290 p-430 q+126 .
\end{aligned}
$$




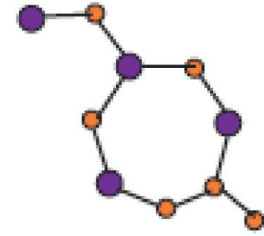

Figure 1: Unit cell of $\mathrm{Si}_{2} \mathrm{C}_{3} \mathrm{I}[p, q]$.

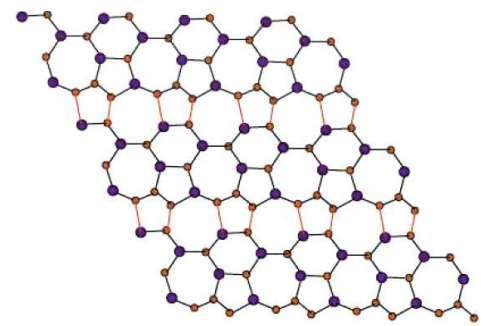

Figure 2: $\mathrm{Si}_{2} \mathrm{C}_{3} \mathrm{I}[p, q]$ for $p=4, q=3$.

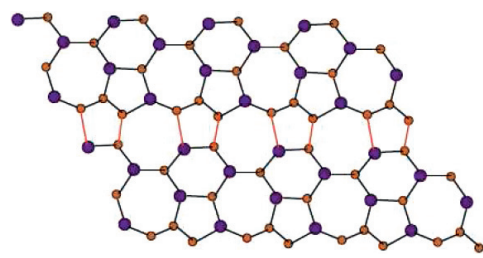

Figure 3: $\mathrm{Si}_{2} \mathrm{C}_{3} \mathrm{I}[p, q]$ for $p=4, q=1$.

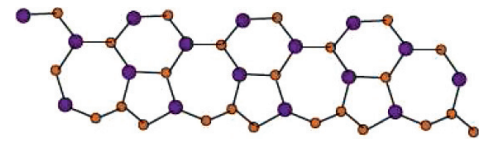

Figure 4: $\mathrm{Si}_{2} \mathrm{C}_{3} \mathrm{I}[p, q]$ for $p=4, q=3$.

TABLE 1: Degree-based edge partition of $\mathrm{Si}_{2} \mathrm{C}_{3} \mathrm{I}[p, q]$.

\begin{tabular}{lc}
\hline$\left(d_{u}, d_{v}\right)$ & Frequency \\
\hline$(1,2)$ & 1 \\
$(1,3)$ & 1 \\
$(2,2)$ & $p+2 q$ \\
$(2,3)$ & $6 p-1+8(q-1)$ \\
$(3,3)$ & $15 p q-9 p-13 q+7$ \\
\hline
\end{tabular}

Theorem 2. Let $G$ be the graph of silicon carbide $\mathrm{Si}_{2} \mathrm{C}_{3} I[p, q]$. Then, the first and second hyper-Gourava indices are

(1) $\mathrm{HGO}_{1}(G)=3375 p q-1235 p-1829 q+566$,

(2) $\mathrm{HGO}_{2}(G)=43740 p q-20588 p-30196 q+12492$.

Proof. From the edge partition of $\mathrm{Si}_{2} \mathrm{C}_{3} \mathrm{I}[p, q]$ given in Table 1, we have

(1) The first hyper-Gourava index for $\mathrm{Si}_{2} \mathrm{C}_{3} \mathrm{I}[p, q]$ is

$$
\begin{aligned}
\operatorname{HGO}_{1}(G)= & \sum_{u v \in E(G)}\left[\left(d_{u}+d_{v}\right)+\left(d_{u} \cdot d_{v}\right)^{2}\right] \\
= & {[(1 \times 2)+(1 \times 2)]^{2}(1)+[(1+3)+(1 \times 3)]^{2}(1) } \\
& +[(2+2)+(2 \times 2)]^{2}(p+2 q) \\
& +[(2+3)+(2 \times 3)]^{2}(6 p+8 q-9) \\
& +[(3+3)+(3 \times 3)]^{2}(15 p q-9 p-13 q+7) \\
= & 3375 p q-1235 p-1829 q+566 .
\end{aligned}
$$

(2) The second hyper-Gourava index for $\mathrm{Si}_{2} \mathrm{C}_{3} \mathrm{I}[p, q]$ is

$$
\begin{aligned}
\mathrm{HGO}_{2}(G)= & \sum_{u v \in E(G)}\left[\left(d_{u}+d_{v}\right) \cdot\left(d_{u} \cdot d_{v}\right)^{2}\right] \\
= & {[(1+2) \times(1+2)]^{2}(1)+[(1+3) \times(1+3)]^{2}(1) } \\
& +[(2+2) \times(2+2)]^{2}(p+2 q) \\
& +[(2+3) \times(2+3)]^{2}(6 p+8 q-9) \\
& +[(3+3) \times(3 \times 3)]^{2}(15 p q-9 p-13 q+7) \\
= & 43740 p q-20588 p-30196 q+12492
\end{aligned}
$$

3.1.2. Gourava Indices for Silicon Carbide $\mathrm{Si}_{2} \mathrm{C}_{3}-\mathrm{II}[p, q]$. The molecular graphs of silicon carbide $\mathrm{Si}_{2} \mathrm{C}_{3}-\mathrm{II}[p, q]$ are shown in Figures 5-8, where Figure 5 shows the unit cell of $\mathrm{Si}_{2} \mathrm{C}_{3}-\mathrm{II}[p, q]$, Figure 6 shows $\mathrm{Si}_{2} \mathrm{C}_{3}-\mathrm{II}[p, q]$ for $p=3$, $q=3$, Figure 7 shows $\mathrm{Si}_{2} \mathrm{C}_{3}-\mathrm{II}[p, q]$ for $p=5, q=1$, and Figure 8 shows $\mathrm{Si}_{2} \mathrm{C}_{3}-\mathrm{II}[p, q]$ for $p=5, q=2$. The edge partition of the edge set of $\mathrm{Si}_{2} \mathrm{C}_{3}-\mathrm{II}[p, q]$ based on the degree of the end vertex is given in Table 2 .

Theorem 3. Let $G$ be the graph of silicon carbide $\mathrm{Si}_{2} \mathrm{C}_{3}-\mathrm{II}[p, q]$. Then, the first and second Gourava indices are

(1) $G O_{1}(G)=225 p q-91 p-91 q+28$,

(2) $\mathrm{GO}_{2}(G)=810 p q-430 p-430 q+198$.

Proof. From the edge partition of $\mathrm{Si}_{2} \mathrm{C}_{3}-\mathrm{II}[p, q]$ given in Table 2, we have

(1) The first Gourava index for $\mathrm{Si}_{2} \mathrm{C}_{3} \mathrm{I}[p, q]$ is

$$
\begin{aligned}
\mathrm{GO}_{1}(G)= & \sum_{u v \in E(G)}\left[\left(d_{u}+d_{v}\right)+\left(d_{u} \cdot d_{v}\right)\right] \\
= & {[(1+2)+(1 \times 2)](2)+[(1+3)+(1 \times 3)](1) } \\
& +[(2+2)+(2 \times 2)](2 p+2 q) \\
& +[(2+3)+(2 \times 3)](8 p+8 q-14) \\
& +[(3+3)+(3 \times 3)](15 p q-13 p-13 q+11) \\
= & 225 p q-91 p-91 q+28 .
\end{aligned}
$$




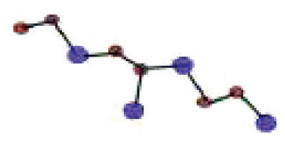

FIgURe 5: Unit cell of $\mathrm{Si}_{2} \mathrm{C}_{3}-\mathrm{II}[p, q]$.

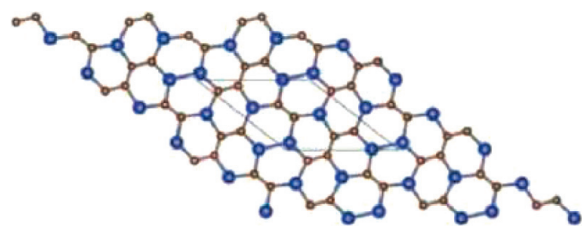

Figure 6: $\mathrm{Si}_{2} \mathrm{C}_{3}-\mathrm{II}[p, q]$ for $p=3, q=3$.

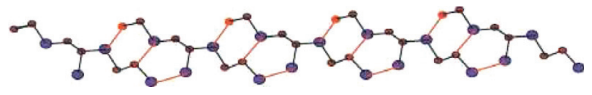

Figure $7: \mathrm{Si}_{2} \mathrm{C}_{3}-\mathrm{II}[p, q]$ for $p=5, q=1$.

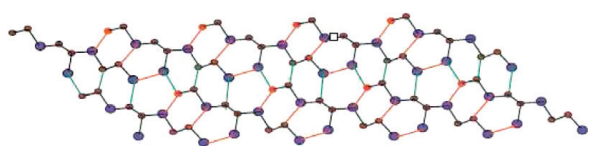

Figure 8: $\mathrm{Si}_{2} \mathrm{C}_{3}-\mathrm{II}[p, q]$ for $p=5, q=2$.

TABle 2: Degree-based edge partition of $\mathrm{Si}_{2} \mathrm{C}_{3}-\mathrm{II}[p, q]$.

\begin{tabular}{lc}
\hline$\left(d_{u}, d_{v}\right)$ & Frequency \\
\hline$(1,2)$ & 2 \\
$(1,3)$ & 1 \\
$(2,2)$ & $2 p+2 q$ \\
$(2,3)$ & $8 p+8 q-14$ \\
$(3,3)$ & $15 p q-13 p-13 q+11$ \\
\hline
\end{tabular}

(2) The second Gourava index for $\mathrm{Si}_{2} \mathrm{C}_{3}-\mathrm{II}[p, q]$ is

$$
\begin{aligned}
\mathrm{GO}_{2}(G)= & \sum_{u v \in E(G)}\left[\left(d_{u}+d_{v}\right) \cdot\left(d_{u} \cdot d_{v}\right)\right] \\
= & {[(1+2) \times(1 \times 2)](2)+[(1+3) \times(1 \times 3)](1) } \\
& +[(2+2) \times(2 \times 2)](2 p+2 q) \\
& +[(2+3) \times(2 \times 3)](8 p+8 q-14) \\
& +[(3+3) \times(3 \times 3)](15 p q-13 p-13 q+11) \\
= & 1080 p q-680 p-680 q+396
\end{aligned}
$$

Theorem 4. Let $G$ be the graph of silicon carbide $\mathrm{Si}_{2} \mathrm{C}_{3}-\mathrm{II}[p, q]$. Then, the first and second hyper-Gourava indices are

(1) $\mathrm{HGO}_{1}(G)=3375 p q-1829 p-1829 q+880$,

(2) $\mathrm{HGO}_{2}(G)=43740 p q-30196 p-30196 q+19692$.

Proof. From the edge partition of $\mathrm{Si}_{2} \mathrm{C}_{3}-\mathrm{II}[p, q]$ given in Table 2, we have
(1) The first hyper-Gourava index for $\mathrm{Si}_{2} \mathrm{C}_{3}-\mathrm{II}[p, q]$ is

$$
\begin{aligned}
\operatorname{HGO}_{1}(G)= & \sum_{u v \in E(G)}\left[\left(d_{u}+d_{v}\right)+\left(d_{u} \cdot d_{v}\right)\right]^{2} \\
= & {[(1+2)+(1 \times 2)]^{2}(2)+[(1+3)+(1 \times 3)]^{2}(1) } \\
& +[(2+2)+(2 \times 2)]^{2}(2 p+2 q) \\
& +[(2+3)+(2 \times 3)]^{2}(8 p+8 q-14) \\
& +[(3+3)+(3 \times 3)]^{2}(15 p q-3 p-13 q+11) \\
= & 3375 p q-1829 p-1829 q+880
\end{aligned}
$$

(2) The second hyper-Gourava index for $\mathrm{Si}_{2} \mathrm{C}_{3}-\mathrm{II}[p, q]$ is

$$
\begin{aligned}
\mathrm{HGO}_{2}(G)= & \sum_{u v \in E(G)}\left[\left(d_{u}+d_{v}\right) \cdot\left(d_{u} \cdot d_{v}\right)\right]^{2} \\
= & {[(1+2) \times(1 \times 2)]^{2}(2)+[(1+3) \times(1 \times 3)]^{2}(1) } \\
& +[(2+2) \times(2 \times 2)]^{2}(2 p+2 q) \\
& +[(2+3) \times(2 \times 3)]^{2}(8 p+8 q-14) \\
& +[(3+3) \times(3 \times 3)]^{2}(15 p q-13 p-13 q+11) \\
= & 43740 p q-30196 p-30196 q+19692 .
\end{aligned}
$$

3.1.3. Gourava Indices for Silicon Carbide $\mathrm{Si}_{2} \mathrm{C}_{3}-\mathrm{III}[p, q]$. The unit cell of $\mathrm{Si}_{2} \mathrm{C}_{3} \mathrm{III}[p, q]$ is shown in Figure 9. The 2D lattice graphs of $\mathrm{Si}_{2} \mathrm{C}_{3}-\mathrm{I}[5,1], \mathrm{Si}_{2} \mathrm{C}_{3}-\mathrm{I}[5,2]$, and $\mathrm{Si}_{2} \mathrm{C}_{3}-$ $\mathrm{I}[5,4]$ are shown in Figures $10-12$, respectively. The edge partition of the edge set of $\operatorname{Si}_{2} \mathrm{C}_{3} \mathrm{III}[p, q]$ based on the degrees of end vertices is given in Table 3.

Theorem 5. Let $G$ be the graph of silicon carbide $\mathrm{Si}_{2} \mathrm{C}_{3} \mathrm{III}[p, q]$. Then, the first and second Gourava indices are

(1) $G O_{1}(G)=225 p q-62 p-91 q+18$,

(2) $\mathrm{GO}_{2}(G)=810 p q-300 p-430 q+128$.

Proof. From the edge partition of $\mathrm{Si}_{2} \mathrm{C}_{3} \mathrm{III}[p, q]$ given in Table 3, we have

(1) The first Gourava index for $\operatorname{Si}_{2} \mathrm{C}_{3} \mathrm{III}[p, q]$ is

$$
\begin{aligned}
\mathrm{GO}_{1}(G)= & \sum_{u v \in E(G)}\left[\left(d_{u}+d_{v}\right)+\left(d_{u} \cdot d_{v}\right)\right] \\
= & (1 \times 3)](1)+[(2+2)+(2 \times 2)](2 p+2 q) \\
& +[(2+3)+(2 \times 3)](8 p+8 q-14) \\
& +[(3+3)+(3 \times 3)](15 p q-13 p-13 q+11) \\
= & 225 p q-62 p-91 q+18 .
\end{aligned}
$$




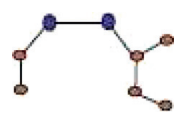

FIgURe 9: Unit cell.

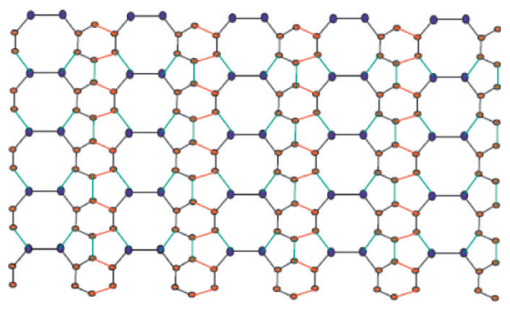

Figure 10: $\mathrm{Si}_{2} \mathrm{C}_{3}-\mathrm{I}[5,1]$.

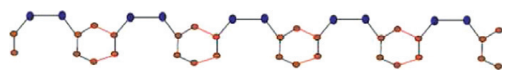

Figure 11: $\mathrm{Si}_{2} \mathrm{C}_{3}-\mathrm{I}[5,2]$.

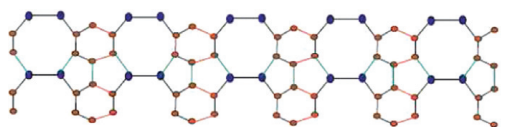

Figure 12: $\mathrm{Si}_{2} \mathrm{C}_{3}-\mathrm{I}[5,4]$.

TAble 3: Degree-based edge partition of $\mathrm{Si}_{2} \mathrm{C}_{3} \mathrm{III}[p, q]$.

\begin{tabular}{lc}
\hline$\left(d_{u}, d_{v}\right)$ & Frequency \\
\hline$(1,3)$ & 2 \\
$(2,2)$ & $2 q+2$ \\
$(2,3)$ & $8 p+8 q-12$ \\
$(3,3)$ & $15 p q-10 p-13 q+8$ \\
\hline
\end{tabular}

(2) The second Gourava index for $\mathrm{Si}_{2} \mathrm{C}_{3} \mathrm{III}[p, q]$ is

$$
\begin{aligned}
\mathrm{GO}_{2}(G)= & \sum_{u v \in E(G)}\left[\left(d_{u}+d_{v}\right) \cdot\left(d_{u} \cdot d_{v}\right)\right] \\
= & {[(1+3) \times(1 \times 3)](1)+[(2+2) \times(2 \times 2)](2 p+2 q) } \\
& +[(2+3) \times(2 \times 3)](8 p+8 q-14) \\
& +[(3+3) \times(3 \times 3)](15 p q-13 p-13 q+11) \\
= & 810 p q-300 p-430 q+128 .
\end{aligned}
$$

Theorem 6. Let $G$ be the graph of silicon carbide $\mathrm{Si}_{2} \mathrm{C}_{3} \mathrm{III}[p, q]$. Then, the first and second hyper-Gourava indices are

(1) $H_{G O}(G)=3375 p q-1282 p-1829 q+500$,

(2) $\mathrm{HGO}_{2}(G)=43740 p q-21960 p-30196 q+13328$.

Proof. From the edge partition of $\mathrm{Si}_{2} \mathrm{C}_{3} \mathrm{III}[p, q]$ given in Table 3, we have
(1) The first hyper-Gourava index for $\mathrm{Si}_{2} \mathrm{C}_{3} \mathrm{III}[p, q]$ is

$$
\begin{aligned}
\mathrm{HGO}_{1}(G)= & \sum_{u v E(G)}\left[\left(d_{u}+d_{v}\right)+\left(d_{u} \cdot d_{v}\right)\right]^{2} \\
= & {[(1+3)+(1 \times 3)]^{2}(1)+[(2+2)+(2 \times 2)]^{2}(2 p+2 q) } \\
& +[(2+3)+(2 \times 3)]^{2}(8 p+8 q-14) \\
& +[(3+3)+(3 \times 3)]^{2}(15 p q-3 p-13 q+11) \\
= & 3375 p q-1282 p-1829 q+500 .
\end{aligned}
$$

(2) The second hyper-Gourava index for $\mathrm{Si}_{2} \mathrm{C}_{3} \mathrm{III}[p, q]$ is

$$
\begin{aligned}
\mathrm{HGO}_{2}(G)= & \sum_{u v E(G)}\left[\left(d_{u}+d_{v}\right) \cdot\left(d_{u} \cdot d_{v}\right)\right]^{2} \\
= & {[(1+3) \times(1 \times 3)]^{2}(1)+[(2+2) \times(2 \times 2)]^{2}(2 p+2 q) } \\
& +[(2+3) \times(2 \times 3)]^{2}(8 p+8 q-14) \\
& +[(3+3) \times(3 \times 3)]^{2}(15 p q-13 p-13 q+11) \\
= & 43740 p q-21960 p-30196 q+13328 .
\end{aligned}
$$

3.1.4. Gourava Indices for Silicon Carbide $\mathrm{SiC}_{3}-\mathrm{III}[p, q]$. The unit cell of $\mathrm{SiC}_{3}-\mathrm{III}[p, q]$ is shown in Figure 13. The 2D lattice graphs of $\mathrm{SiC}_{3}-\mathrm{III}[5,1], \mathrm{SiC}_{3}-\mathrm{III}[5,2]$, and $\mathrm{SiC}_{3}-$ III $[5,4]$ are shown in Figures 14-16, respectively. The edge partition of the edge set of $\mathrm{SiC}_{3}-\mathrm{III}[p, q]$ based on the degrees of end vertices is given in Table 4 .

Theorem 7. Let $G$ be the graph of silicon carbide $\mathrm{SiC}_{3} \mathrm{III}[p, q]$. Then, the first and second Gourava indices are

(1) $G O_{1}(G)=480 p q-90 p-60 q+25$,

(2) $\mathrm{GO}_{2}(G)=648 p q-420 p-280 q+168$.

Proof. From the edge partition of the edge set of $\mathrm{SiC}_{3} \mathrm{III}[p, q]$ given in Table 4 , we have

(1) The first Gourava index for $\mathrm{SiC}_{3} \mathrm{III}[p, q]$ is

$$
\begin{aligned}
\mathrm{GO}_{1}(G)= & \sum_{u v \in E(G)}\left[\left(d_{u}+d_{v}\right)+\left(d_{u} \cdot d_{v}\right)\right] \\
= & {[(1+2)+(1 \times 2)](2)+[(1+3)+(1 \times 3)](1) } \\
& +[(2+2)+(2 \times 2)](3 p+2 q-3) \\
& +[(2+3)+(2 \times 3)](6 p+4 q-8) \\
& +[(3+3)+(3 \times 3)](12 p q-12 p-8 q+8) \\
= & 480 p q-90 p-60 q+25 .
\end{aligned}
$$

(2) The second Gourava index for $\mathrm{SiC}_{3} \mathrm{III}[p, q]$ is 


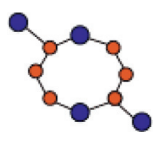

FIgURE 13: Unit cell.

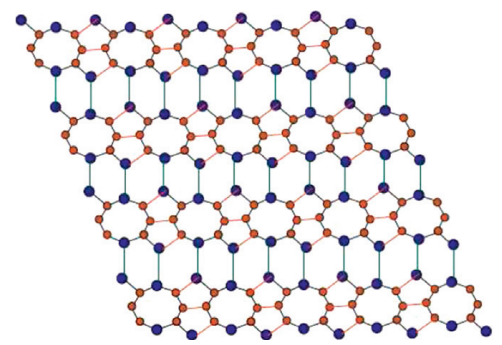

FIgURE 14: $\mathrm{SiC}_{3}-\mathrm{III}[5,1]$.

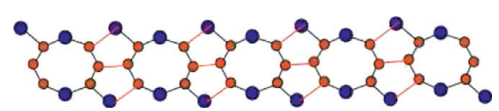

Figure 15: $\mathrm{SiC}_{3}-\mathrm{III}[5,2]$.

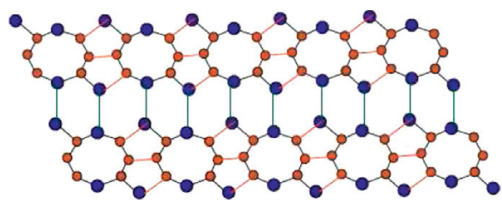

Figure 16: $\mathrm{SiC}_{3}-\mathrm{III}[5,4]$.

TABle 4: Degree-based edge partition of $\mathrm{SiC}_{3} \mathrm{III}[p, q]$.

\begin{tabular}{lc}
\hline$\left(d_{u}, d_{v}\right)$ & Frequency \\
\hline$(1,2)$ & 2 \\
$(1,3)$ & 1 \\
$(2,2)$ & $3 p+2 q-3$ \\
$(2,3)$ & $6 p+4 q-8$ \\
$(3,3)$ & $12 p q-12 p-8 q+8$ \\
\hline
\end{tabular}

$$
\begin{aligned}
\mathrm{GO}_{2}(G)= & \sum_{u v \in E(G)}\left[\left(d_{u}+d_{v}\right) \cdot\left(d_{u} \cdot d_{v}\right)\right] \\
= & {[(1+2) \times(1 \times 2)](2)+[(1+3) \times(1 \times 3)](1) } \\
& +[(2+2) \times(2 \times 2)](3 p+2 q-3) \\
& +[(2+3) \times(2 \times 3)](6 p+4 q-8) \\
& +[(3+3) \times(3 \times 3)](12 p q-12 p-8 q+8) \\
= & 648 p q-420 p-280 q+168 .
\end{aligned}
$$

Theorem 8. Let $G$ be the graph of silicon carbide $\mathrm{SiC}_{3} \mathrm{III}[p, q]$. Then, the first and second hyper-Gourava indices are

(1) $\mathrm{HGO}_{1}(G)=2700 p q-1782 p-118 q+739$,

(2) $\mathrm{HGO}_{2}(G)=34992 p q-28824 p-19216 q+15576$.
Proof. From the edge partition of the edge set of $\mathrm{SiC}_{3}$ III $[p, q]$ given in Table 4 , we have

(1) The first hyper-Gourava index for $\operatorname{SiC}_{3} \mathrm{III}[p, q]$ is

$$
\begin{aligned}
\mathrm{HGO}_{1}(G)= & \sum_{u v \in E(G)}\left[\left(d_{u}+d_{v}\right)+\left(d_{u} \cdot d_{v}\right)\right]^{2} \\
= & {[(1+2)+(1 \times 2)]^{2}(2)+[(1+3)+(1 \times 3)]^{2}(1) } \\
& +[(2+2)+(2 \times 2)]^{2}(2 p+2 q) \\
& +[(2+3)+(2 \times 3)]^{2}(8 p+8 q-14) \\
& +[(3+3)+(3 \times 3)]^{2}(15 p q-3 p-13 q+11) \\
= & 2700 p q-1782 p-118 q+739 .
\end{aligned}
$$

(2) The second hyper-Gourava index for $\operatorname{SiC}_{3} \mathrm{III}[p, q]$ is

$$
\begin{aligned}
\mathrm{HGO}_{2}(G)= & \sum_{u v \in E(G)}\left[\left(d_{u}+d_{v}\right) \cdot\left(d_{u} \cdot d_{v}\right)\right]^{2} \\
= & {[(1+2) \times(1 \times 2)]^{2}(2)+[(1+3) \times(1 \times 3)]^{2}(1) } \\
& +[(2+2) \times(2 \times 2)]^{2}(2 p+2 q) \\
& +[(2+3) \times(2 \times 3)]^{2}(8 p+8 q-14) \\
& +[(3+3) \times(3 \times 3)]^{2}(15 p q-13 p-13 q+11) \\
= & 34992 p q-28824 p-19216 q+15576 .
\end{aligned}
$$

3.1.5. Graphical Comparison of Results of Silicone Carbides. In Figures 17-20, we can observe that the behavior of all indices is exponentially increasing with respect to the involved parameters.

Codes for plotting the first and second Gourava indices for silicon carbide $\mathrm{Si}_{2} \mathrm{C}_{3} \mathrm{I}[p, r]$ are given as follows:

$$
\begin{aligned}
& \operatorname{plot} 3 d(225 * p * q-61 * p-91 * q+18, p=0 . .1, q=0 . .1, \\
& \quad \text { colour }=\text { red }), \\
& \text { plot3d }(810 * p * q-290 * p-430 * q+126, p=0 . .1, q=0 . .1, \\
& \quad \text { colour }=\text { green }) .
\end{aligned}
$$

3.2. Gourava Indices for Bismuth Triiodide. $\mathrm{BiI}_{3}$ is an inorganic compound which is the result of the reaction between iodine and bismuth, which inspired the enthusiasm for subjective inorganic investigations [46]. $\mathrm{BiI}_{3}$ is an excellent inorganic compound and is very useful in qualitative inorganic analysis [47]. It has been proven that $\mathrm{Bi}$-doped glass optical strands are one of the most promising dynamic laser media. Different kinds of Bi-doped fiber strands have been created and have been used to construct Bi-doped fiber lasers and optical loudspeakers [48]. Layered $\mathrm{BiI}_{3}$ gemstones are considered to be a three-layered stack structure in which a plane of bismuth atoms is sandwiched between iodide 


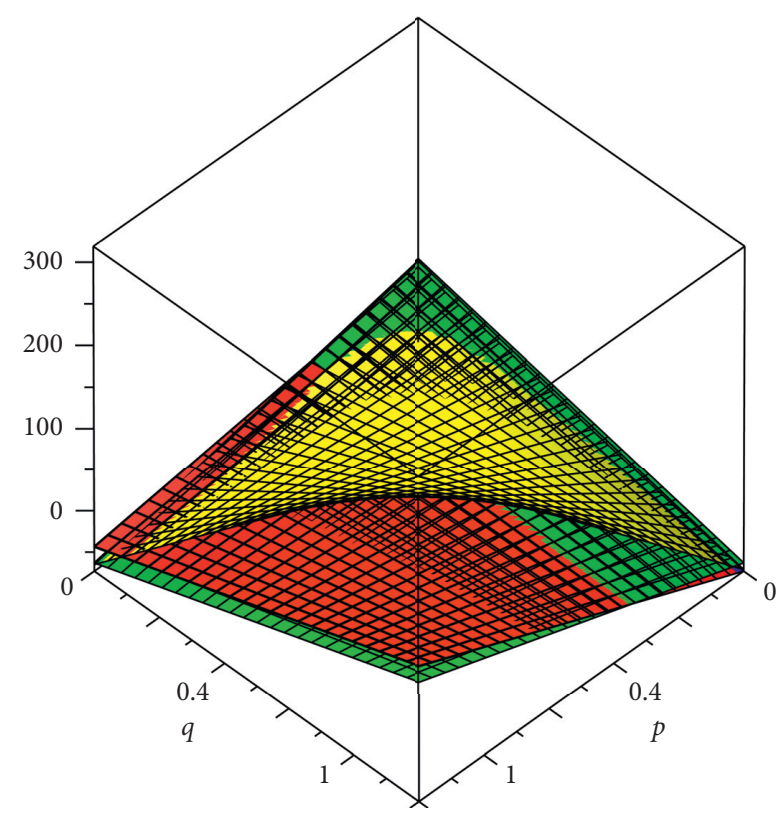

Figure 17: Comparison of the first Gourava index.

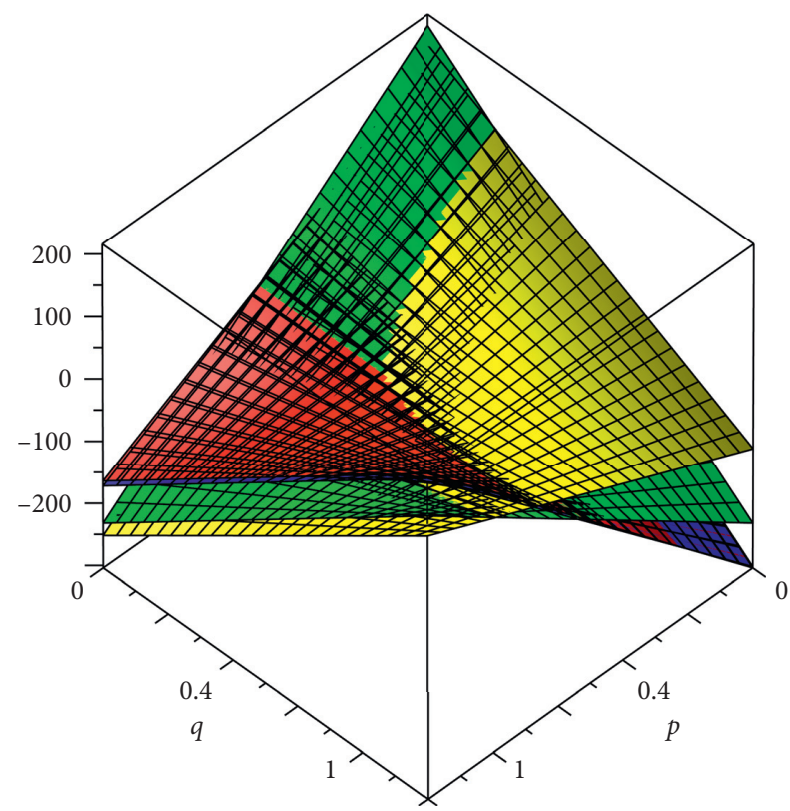

FIGURE 18: Comparison of the second Gourava index.

particle planes to form a continuous plane [49]. The periodic superposition of the three layers forms diamond-shaped $\mathrm{BiI}_{3}$ crystals with $R-3$ symmetry $[50,51]$. A progressive stack of I - Bi - I layers forms a hexagonal structure with symmetry [52]. A jewel of $\mathrm{BiI}_{3}$ has been integrated in [46]. We referred to [6] for the topological study of bismuth triiodide.

3.2.1. Bismuth Triiodide Chain $m-\mathrm{BiI}_{3}$. The molecular graph of the unit cell of $m-\mathrm{BiI}_{3}$ is shown in Figure 21. From Figure 22, we can see that the molecular graph of $m-\mathrm{BiI}_{3}$ has two types of edge sets. The edge partition of the edge set of $m-\mathrm{BiI}_{3}$ is given in Table 5 .

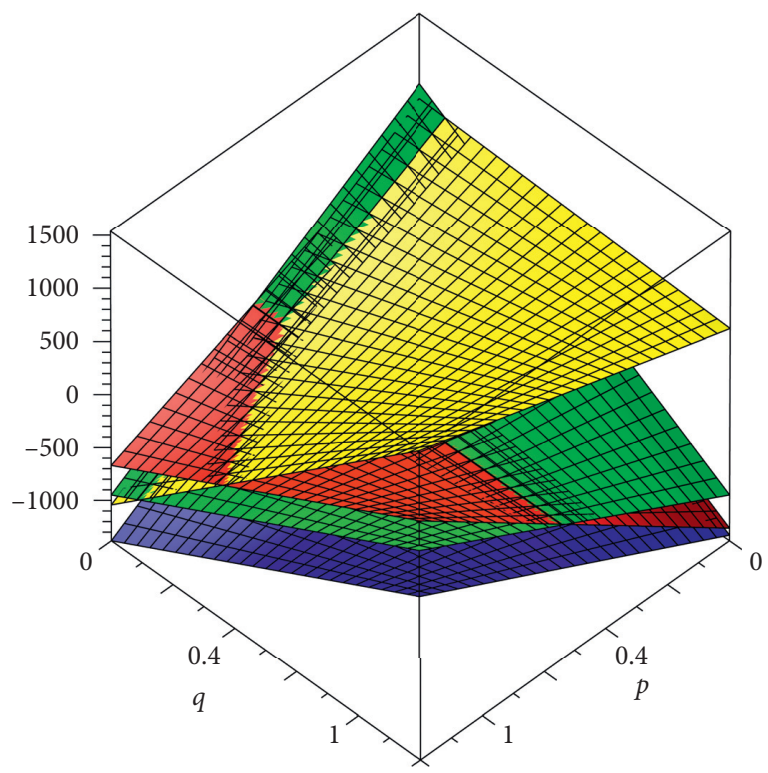

FIgURE 19: Comparison of the first hyper-Gourava index.

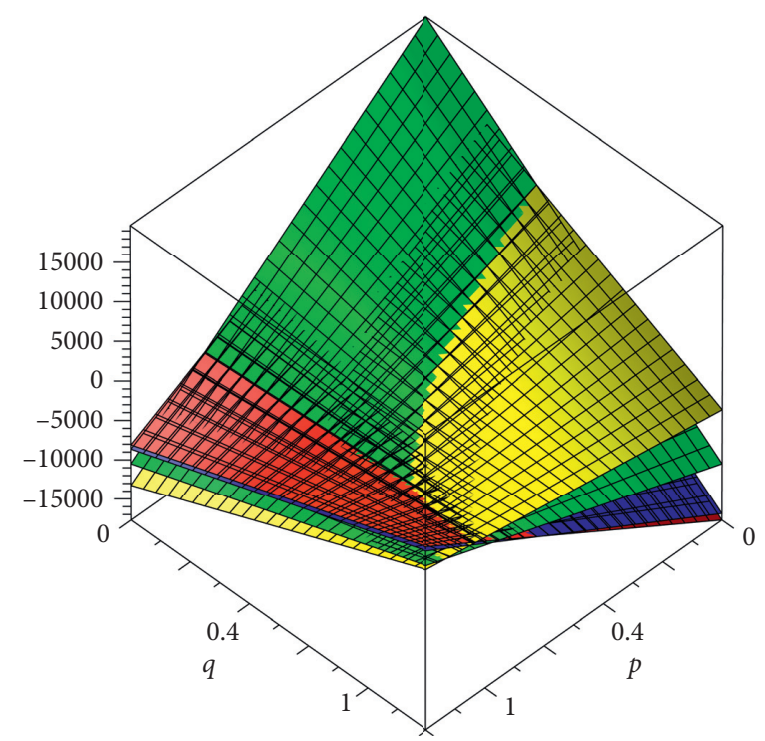

FIGURE 20: Comparison of the second hyper-Gourava index.

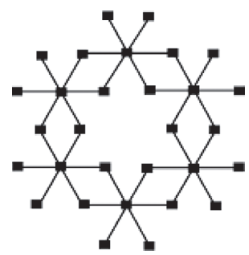

Figure 21: Unit cell (bismuth triiodide).

Theorem 9. Let $G$ be the graph of the bismuth triiodide chain $m-\mathrm{BiI}_{3}$. Then, the first and second Gourava indices are

(1) $G O_{1}(G)=452 m+184$,

(2) $\mathrm{GO}_{2}(G)=2088 m+720$. 


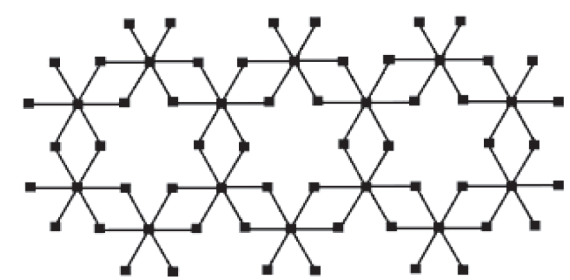

FIgURE 22: The chain for $m=3$ (bismuth triiodide).

TABLE 5: Degree-based edge partition of $m-\operatorname{Bil}_{3}[m, n]$ of end vertices of each edge.

\begin{tabular}{lc}
\hline$\left(d_{u}, d_{v}\right)$ & Frequency \\
\hline$(1,6)$ & $4 m+8$ \\
$(2,6)$ & $20 m+4$ \\
\hline
\end{tabular}

Proof. From the edge partition of the edge set of $m-\mathrm{BiI}_{3}$ given in Table 5, we have

(1) The first Gourava index for $m-\mathrm{BiI}_{3}$ is

$$
\begin{aligned}
\mathrm{GO}_{1}(G)= & \sum_{u v \in E(G)}\left[\left(d_{u}+d_{v}\right)+\left(d_{u} \cdot d_{v}\right)\right] \\
= & {[(1+6)+(1 \times 6)](4 m+8) } \\
& +[(2+6)+(2 \times 6)](20 m+4) \\
= & 452 m+184 .
\end{aligned}
$$

(2) The second Gourava index for $m-\mathrm{BiI}_{3}$ is

$$
\begin{aligned}
\mathrm{GO}_{2}(G)= & \sum_{u v \in E(G)}\left[\left(d_{u}+d_{v}\right) \cdot\left(d_{u} \cdot d_{v}\right)\right] \\
= & {[(1+6) \times(1 \times 6)](4 m+8) } \\
& +[(2+6) \times(2 \times 6)](20 m+4) \\
= & 2088 m+720 .
\end{aligned}
$$

Theorem 10. Let $G$ be the graph of the bismuth triiodide chain $m-\mathrm{BiI}_{3}$. Then, the first and second hyper-Gourava indices are

(1) $\mathrm{HGO}_{1}(G)=8676 m+2952$,

(2) $\mathrm{HGO}_{2}(G)=191376 m+93376$.

Proof. From the edge partition of the edge set of $m-\mathrm{BiI}_{3}$ given in Table 5 , we have

(1) The first hyper-Gourava index for $m-\mathrm{BiI}_{3}$ is

$$
\begin{aligned}
\mathrm{HGO}_{1}(G)= & \sum_{u v \in E(G)}\left[\left(d_{u}+d_{v}\right)+\left(d_{u} \cdot d_{v}\right)\right]^{2} \\
= & {[(1+6)+(1 \times 6)]^{2}(4 m+8) } \\
& +[(2+6)+(2 \times 6)]^{2}(20 m+4) \\
= & 8676 m+2952 .
\end{aligned}
$$

(2) The second hyper-Gourava index for $m-\mathrm{BiI}_{3}$ is

$$
\begin{aligned}
\operatorname{HGO}_{2}(G)= & \sum_{u v \in E(G)}\left[\left(d_{u}+d_{v}\right) \cdot\left(d_{u} \cdot d_{v}\right)\right]^{2} \\
= & {[(1+6) \times(1 \times 6)]^{2}(4 m+8) } \\
& +[(2+6) \times(2 \times 6)]^{2}(20 m+4) \\
= & 191376 m+93376 .
\end{aligned}
$$

3.2.2. Bismuth Triiodide Sheet $\mathrm{BiI}_{3}(m \times n)$. The molecular graph of the bismuth triiodide sheet $\operatorname{BiI}_{3}(m \times n)$ is shown in Figure 23. It can be observed from Figure 23 that the edge set of the bismuth triiodide sheet $\operatorname{BiI}_{3}(m \times n)$ can be divided into three classes based on the degrees of end vertices as shown in Table 6 .

Theorem 11. Let $G$ be the graph of the bismuth triiodide sheet $\mathrm{BiI}_{3}(m \times n)$. Then, the first and second Gourava indices are
(1) $G O_{1}(G)=402 m n+212 m+50 n-28$,
(2) $\mathrm{GO}_{2}(G)=2124 m n+936 m-36 n-216$.

Proof. From the edge partition of the edge set of the bismuth triiodide sheet $\mathrm{BiI}_{3}(m \times n)$ given in Table 6 , we have

(1) The first Gourava index for $\mathrm{BiI}_{3}(m \times n)$ is

$$
\begin{aligned}
\mathrm{GO}_{1}(G)= & \sum_{u v \in E(G)}\left[\left(d_{u}+d_{v}\right)+\left(d_{u} \cdot d_{v}\right)\right] \\
= & {[(1+6)+(1 \times 6)](4 m+4 n+4) } \\
& +[(2+6)+(2 \times 6)](12 m n+8 m+8 n-4) \\
& +[(3+6)+(3 \times 6)](6 m n-6 n) \\
= & 402 m n+212 m+50 n-28 .
\end{aligned}
$$

(2) The second Gourava index for $\mathrm{BiI}_{3}(m \times n)$ is

$$
\begin{aligned}
\mathrm{GO}_{2}(G)= & \sum_{u v \in E(G)}\left[\left(d_{u}+d_{v}\right) \cdot\left(d_{u} \cdot d_{v}\right)\right] \\
= & {[(1+6) \times(1 \times 6)](4 m+4 n+4) } \\
& +[(2+6) \times(2 \times 6)](12 m n+8 m+8 n-4) \\
& +[(3+6) \times(3 \times 6)](6 m n-6 n) \\
= & 2124 m n+936 m-36 n-216 .
\end{aligned}
$$

Theorem 12. Let $G$ be the graph of the bismuth triiodide sheet $\mathrm{BiI}_{3}(m \times n)$. Then, the first and second hyperGourava indices are

(1) $\mathrm{HGO}_{1}(G)=9174 m n+3876 m-498 n-924$,

(2) $\mathrm{HGO}_{2}(G)=268056 m n+80784 m-143036 n-$ 29808 


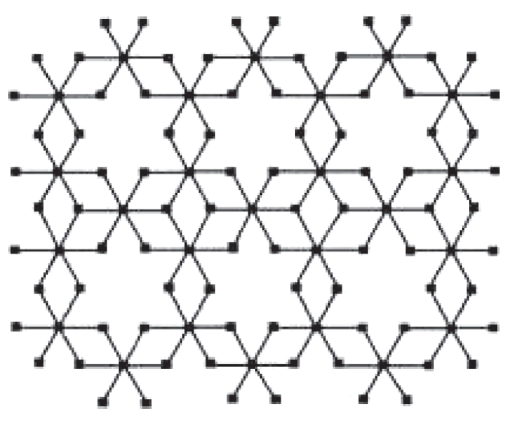

Figure 23: Bismuth triiodide sheet.

TABLE 6: Degree-based edge partition of $\mathrm{BiI}_{3}(m \times n)$.

\begin{tabular}{lc}
\hline$\left(d_{u}, d_{v}\right)$ & Frequency \\
\hline$(1,6)$ & $4(m+n+1)$ \\
$(2,6)$ & $4(3 m n+2 m+2 n-1)$ \\
$(3,6)$ & $6 n(m-1)$ \\
\hline
\end{tabular}

Proof. From the edge partition of the edge set of the bismuth triiodide sheet $\mathrm{BiI}_{3}(m \times n)$ given in Table 6 , we have

(1) The first hyper-Gourava index for $\mathrm{BiI}_{3}(m \times n)$ is

$$
\begin{aligned}
\mathrm{HGO}_{1}(G)= & \sum_{u v \in E(G)}\left[\left(d_{u}+d_{v}\right)+\left(d_{u} \cdot d_{v}\right)\right]^{2} \\
= & {[(1+6)+(1 \times 6)]^{2}(4 m+4 n+4) } \\
& +[(2+6)+(2 \times 6)]^{2}(12 m n+8 m+8 n-4) \\
& +[(3+6)+(3 \times 6)]^{2}(6 m n-6 n) \\
= & 9174 m n+3876 m-498 n-924 .
\end{aligned}
$$

(2) The second hyper-Gourava index for $\operatorname{BiI}_{3}(m \times n)$ is

$$
\begin{aligned}
\mathrm{HGO}_{2}(G)= & \sum_{u v \in E(G)}\left[\left(d_{u}+d_{v}\right) \cdot\left(d_{u} \cdot d_{v}\right)\right]^{2} \\
= & {[(1+6) \times(1 \times 6)]^{2}(4 m+4 n+4) } \\
& +[(2+6) \times(2 \times 6)]^{2}(12 m n+8 m+8 n-4) \\
& +[(3+6) \times(3 \times 6)]^{2}(6 m n-6 n) \\
= & 268056 m n+80784 m-143036 n-29808 .
\end{aligned}
$$

3.3. Graphical Representation. Graphical representation of computed topological indices for the bismuth triiodide chain is shown in Figures 24-27, and the graphical representation of the bismuth triiodide sheet is shown in Figures 28-31.

3.4. Gourava Indices for Dendrimers. In the medication mathematical model, the structure of the drug is addressed as an undirected graph, where each vertex exhibits a

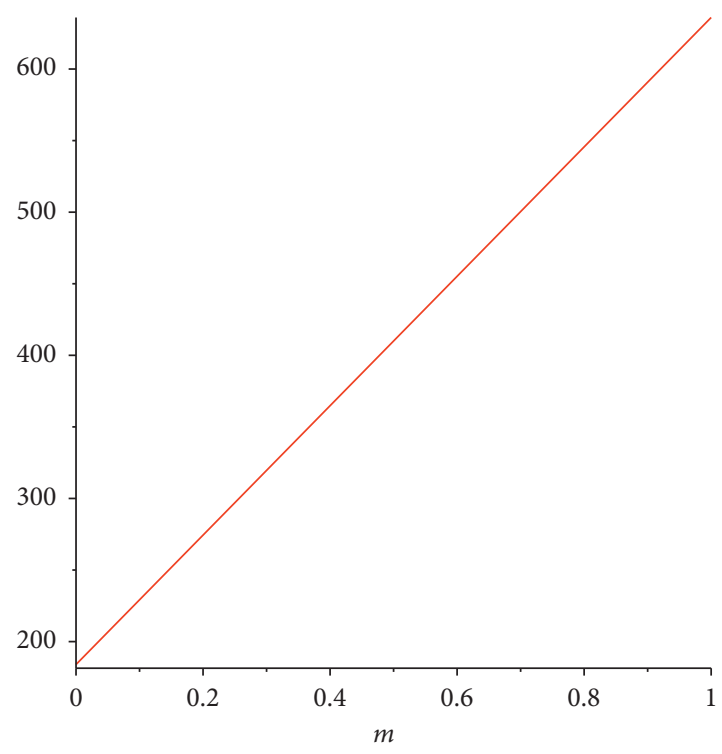

Figure 24: Plots of the first Gourava index for $m-\mathrm{Bil}_{3}$.

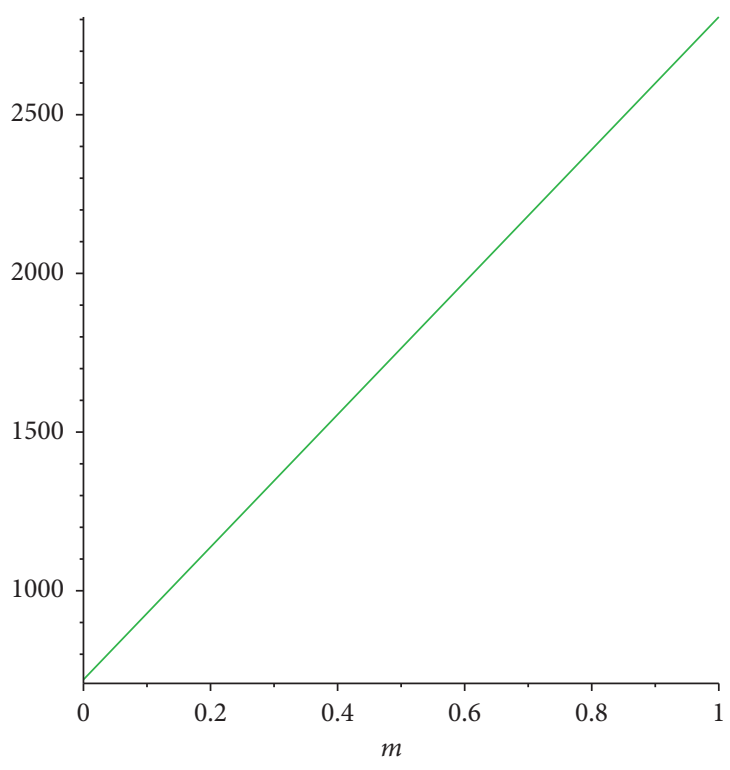

Figure 25: Plots of the second Gourava index for $m-\mathrm{Bil}_{3}$.

molecule and each edge addresses a bond between atoms. A huge number of new drugs have been made each year. From this time forward, it asks for a giant measure of work to choose the pharmacological compound and organic qualities of these new drugs, and such remaining tasks at hand end up being progressively specific and grouped. It requires enough reagent rigging and accomplices to test the exhibitions and the responses of new drugs. Nevertheless, in cut down poor countries and locales (for instance, certain urban networks and countries in South America, Southeast Asia, Africa, and India), there is no sufficient money to settle reagents and apparatus which can be used to gauge the biochemical properties. For topological study of dendrimers, we refer [53-66]. 


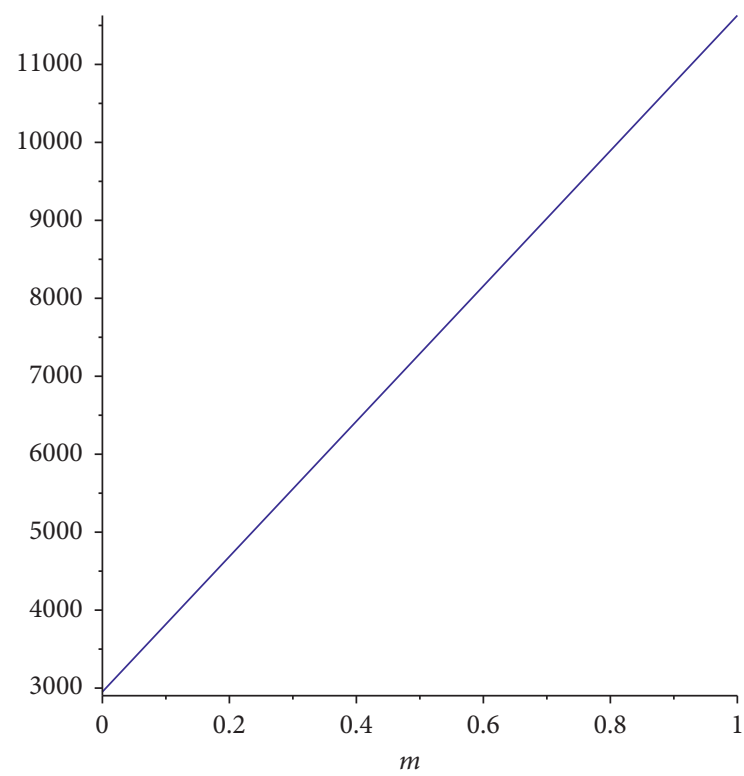

Figure 26: Plots of the first hyper-Gourava index for $m-\mathrm{Bil}_{3}$.

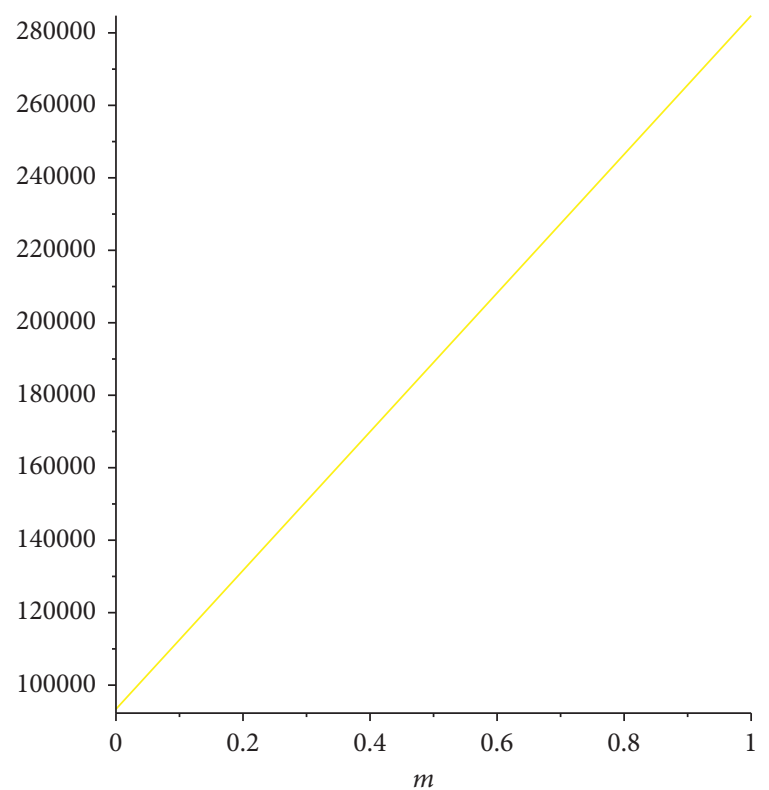

Figure 27: Plots of the second hyper-Gourava index for $m-\mathrm{Bil}_{3}$.

3.4.1. Gourava Indices of Porphyrin Dendrimer $D_{n} P_{n}$. The algebraic graph of porphyrin dendrimer $\mathrm{D}_{n} \mathrm{P}_{n}$ is shown in Figure 32. For porphyrin dendrimer $\mathrm{D}_{n} \mathrm{P}_{n},\left|V\left(\mathrm{D}_{n} \mathrm{P}_{n}\right)\right|=$ $96 n-10$ and $\left|E\left(\mathrm{D}_{n} \mathrm{P}_{n}\right)\right|=105 n-11$. There are six type of edges in the edge set of porphyrin dendrimer, based on the degree of end vertices. Degree-based partition of edges of porphyrin dendrimer $\mathrm{D}_{n} \mathrm{P}_{n}$ is given in Table 7 .

Theorem 13. Let $G$ be the graph of porphyrin dendrimer $D_{n} P_{n}$. Then, the first and second Gourava indices are

(1) $G O_{1}(G)=1169 n-106$,

(2) $\mathrm{GO}_{2}(G)=3478 n-260$.

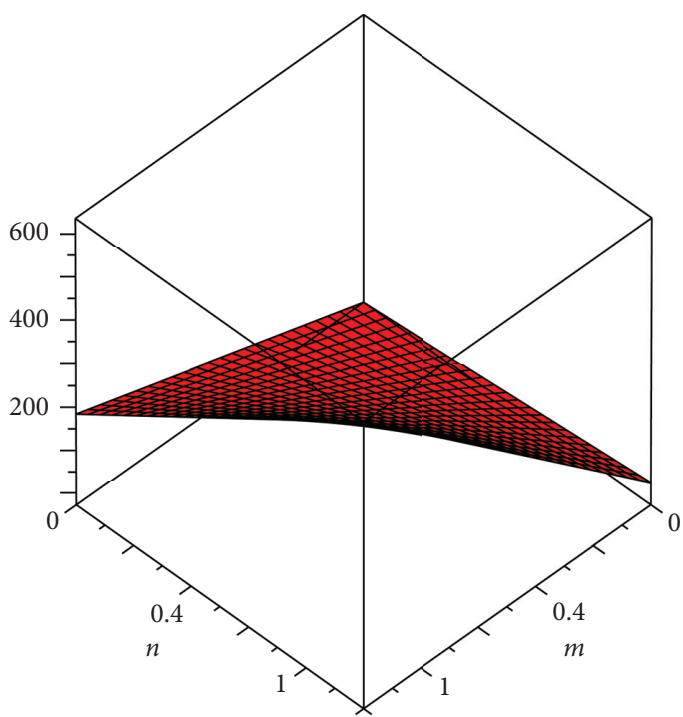

Figure 28: Plots of the first Gourava index for $\operatorname{Bil}_{3}(m \times n)$.

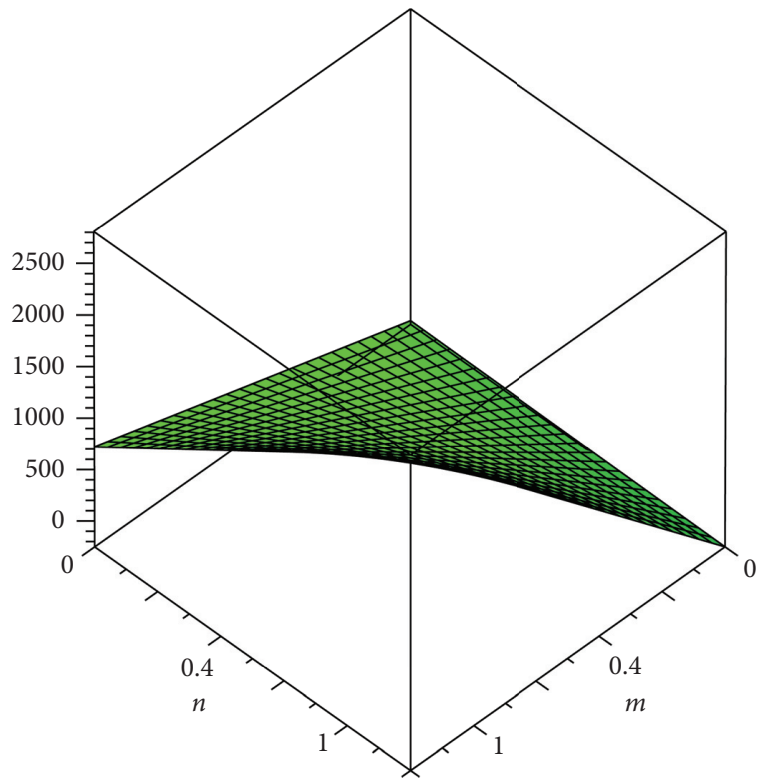

Figure 29: Plots of the second Gourava index for $\operatorname{Bil}_{3}(m \times n)$.

Proof. From the edge partition of $\mathrm{D}_{n} \mathrm{P}_{n}$ given in Table 7, we have

(1) The first Gourava index for $\mathrm{D}_{n} \mathrm{P}_{n}$ is

$$
\begin{aligned}
\mathrm{GO}_{1}(G)= & \sum_{u v \in E(G)}\left[\left(d_{u}+d_{v}\right)+\left(d_{u} \cdot d_{v}\right)\right] \\
= & {[(1+3)+(1 \times 3)](2 n)+[(1+4)+(1 \times 4)](24 n) } \\
& +[(2+2)+(2 \times 2)](10 n-5) \\
& +[(2+3)+(2 \times 3)](48 n-6) \\
& +[(3+3)+(3 \times 3)](13 n)+[(3+4)+(3 \times 4)](8 n) \\
= & 1169 n-106 .
\end{aligned}
$$

(2) The second Gourava index for $\mathrm{D}_{n} \mathrm{P}_{n}$ is 


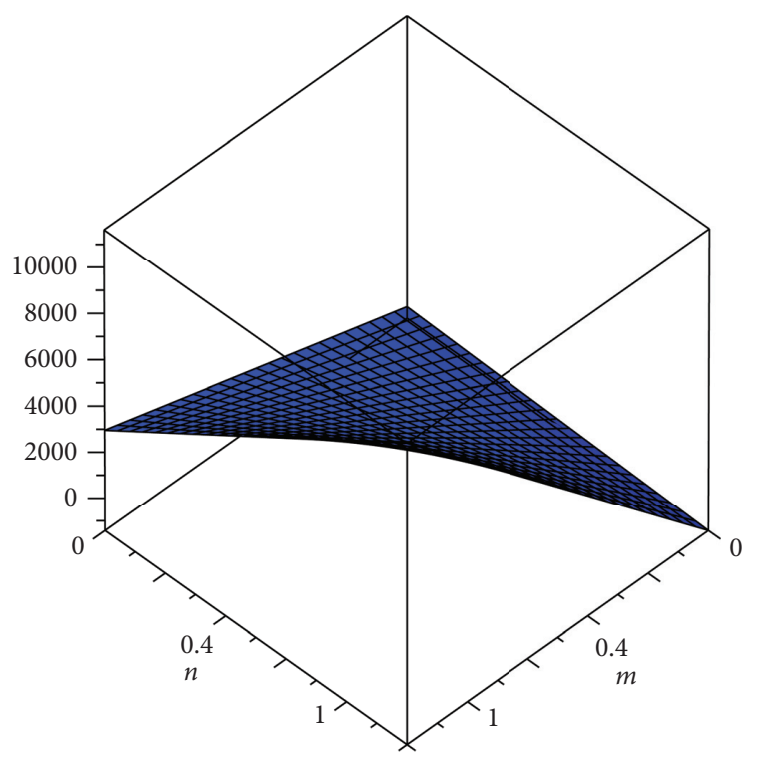

Figure 30: Plots of the first hyper-Gourava index for $\operatorname{Bil}_{3}(m \times n)$.

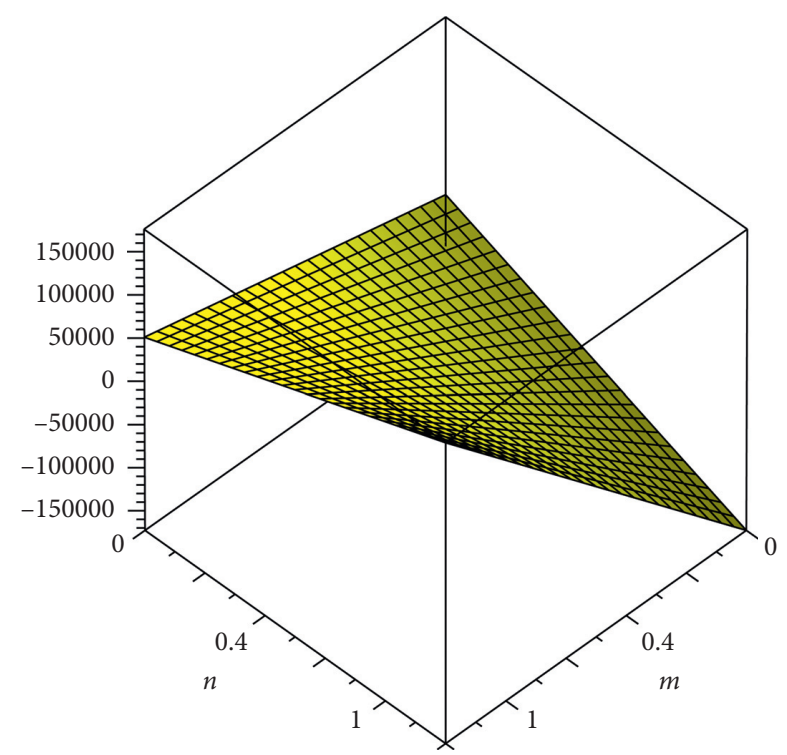

FIGURE 31: Plots of the second hyper-Gourava index for $\operatorname{Bil}_{3}(m \times n)$.

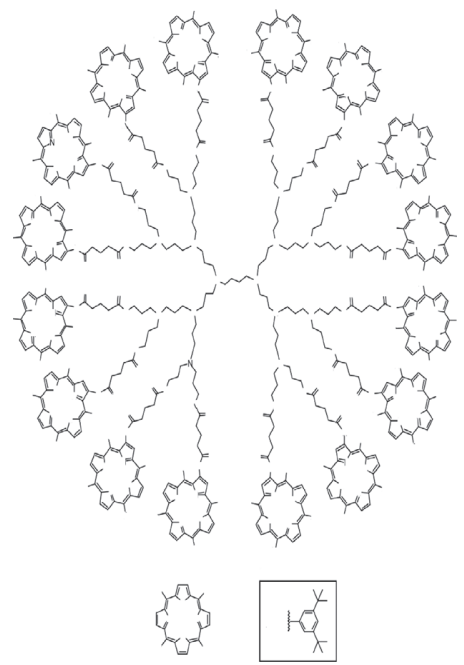

Figure 32: Porphyrin dendrimer $\mathrm{D}_{n} \mathrm{P}_{n}$.
TABLE 7: Degree-based edge partition of $\mathrm{D}_{n} \mathrm{P}_{n}$.

\begin{tabular}{lc}
\hline$\left(d_{u}, d_{v}\right)$ & Frequency \\
\hline$(1,3)$ & $2 n$ \\
$(1,4)$ & $124 n$ \\
$(2,2)$ & $10 n-5$ \\
$(2,3)$ & $48 n-6$ \\
$(3,3)$ & $13 n$ \\
$(3,4)$ & $8 n$ \\
\hline
\end{tabular}

$$
\begin{aligned}
\mathrm{GO}_{2}\left(\mathrm{D}_{n} \mathrm{P}_{n}\right)= & \sum_{u v \in E(G)}\left[\left(d_{u}+d_{v}\right) \cdot\left(d_{u} \cdot d_{v}\right)\right] \\
= & {[(1+3) \times(1 \times 3)](2 n)+[(1+4) \times(1 \times 4)](24 n) } \\
& +[(2+2) \times(2 \times 2)](10 n-5) \\
& +[(2+3) \times(2 \times 3)](48 n-6) \\
& +[(3+3) \times(3 \times 3)](13 n)+[(3+4) \times(3 \times 4)](8 n) \\
= & 3478 n-260 .
\end{aligned}
$$

Theorem 14. Let $G$ be the graph of porphyrin dendrimer $D_{n} P_{n}$. Then, the first and second hyper-Gourava indices are

(1) $\mathrm{HGO}_{1}(G)=13727 n-1046$,

(2) $\mathrm{HGO}_{2}(G)=150004 n-6680$.

Proof. From the edge partition of $\mathrm{D}_{n} \mathrm{P}_{n}$ given in Table 7 , we have

(1) The first hyper-Gourava index for $\mathrm{D}_{n} \mathrm{P}_{n}$ is

$$
\begin{aligned}
\operatorname{HGO}_{1}(G)= & \sum_{u v E(G)}\left[\left(d_{u}+d_{v}\right)+\left(d_{u} \cdot d_{v}\right)\right]^{2} \\
= & {[(1+3)+(1 \times 3)]^{2}(2 n)+[(1+4)+(1 \times 4)]^{2}(24 n) } \\
& +[(2+2)+(2 \times 2)]^{2}(10 n-5) \\
& +[(2+3)+(2 \times 3)]^{2}(48 n-6) \\
& +[(3+3)+(3 \times 3)]^{2}(13 n)+[(3+4)+(3 \times 4)]^{2}(8 n) \\
= & 13727 n-1046 .
\end{aligned}
$$

(2) The second hyper-Gourava index for $\mathrm{D}_{n} \mathrm{P}_{n}$ is

$$
\begin{aligned}
\mathrm{HGO}_{2}(G)= & \sum_{u v \in E(G)}\left[\left(d_{u}+d_{v}\right) \cdot\left(d_{u} \cdot d_{v}\right)\right]^{2} \\
= & {[(1+3) \times(1 \times 3)]^{2}(2 n)+[(1+4) \times(1 \times 4)]^{2}(24 n) } \\
& +[(2+2) \times(2 \times 2)]^{2}(10 n-5) \\
& +[(2+3) \times(2 \times 3)]^{2}(48 n-6) \\
& +[(3+3) \times(3 \times 3)]^{2}(13 n)+[(3+4) \times(3 \times 4)]^{(8 n)} \\
= & 150004 n-6680 .
\end{aligned}
$$


3.4.2. Propyl Ether Imine Dendrimer (PETIM). The algebraic graph of propyl ether imine dendrimer (PETIM) is shown in Figure 33. For propyl ether imine dendrimer (PETIM), $|V(\mathrm{PETIM})|=24.2^{n}-23$ and $|E(\mathrm{PETIM})|=24.2^{n}-24$. There are six type of edges in the edge set of porphyrin dendrimer, based on the degree of end vertices. Degreebased partition of edges of propyl ether imine dendrimer (PETIM) is given in Table 8.

Theorem 15. Let $G$ be the graph of propyl ether imine dendrimer (PETIM). Then, the first and second Gourava indices are

(1) $G O_{1}(G)=66.2^{n}+5 n^{n+1}+8.2^{n+4}-232$,

(2) $\mathrm{GO}_{2}(G)=18.2^{n}+6 . n^{n+1}+16.2^{n+4}-528$.

Proof. From the edge partition of PETIM given in Table 8, we have

(1) The first Gourava index for PETIM is

$$
\begin{aligned}
\mathrm{GO}_{1}(G)= & \sum_{u v \in E(G)}\left[\left(d_{u}+d_{v}\right)+\left(d_{u} \cdot d_{v}\right)\right] \\
= & {[(1+2)+(1 \times 2)]\left(2^{n+1}\right) } \\
& +[(2+2)+(2 \times 2)]\left(2^{n+4}-18\right) \\
& +[(2+3)+(2 \times 3)]\left(6.2^{n}-6\right) \\
= & 66.2^{n}+5 n^{n+1}+8.2^{n+4}-232 .
\end{aligned}
$$

(2) The second Gourava index for PETIM is

$$
\begin{aligned}
\mathrm{GO}_{2}(\mathrm{PETIM})= & \sum_{u v \in E(G)}\left[\left(d_{u}+d_{v}\right) \cdot\left(d_{u} \cdot d_{v}\right)\right] \\
= & {[(1+2) \times(1 \times 2)]\left(2^{n+1}\right) } \\
& +[(2+2) \times(2 \times 2)]\left(2^{n+4}-18\right) \\
& +[(2+3) \times(2 \times 3)]\left(6.2^{n}-6\right) \\
= & 18.2^{n}+6 . n^{n+1}+16.2^{n+4}-528 .
\end{aligned}
$$

Theorem 16. Let $G$ be the graph of propyl ether imine dendrimer (PETIM). Then, the first and second hyperGourava indices are
(1) $\mathrm{HGO}_{1}(G)=726.2^{n}+25 . n^{n+1}+64.2^{n+4}-2120$,
(2) $\mathrm{HGO}_{2}(G)=5400.2^{n}+36 . n^{n+1}+256.2^{n+4}-11808$.

Proof. From the edge partition of PETIM given in Table 8, we have

(1) The first hyper-Gourava index for PETIM is

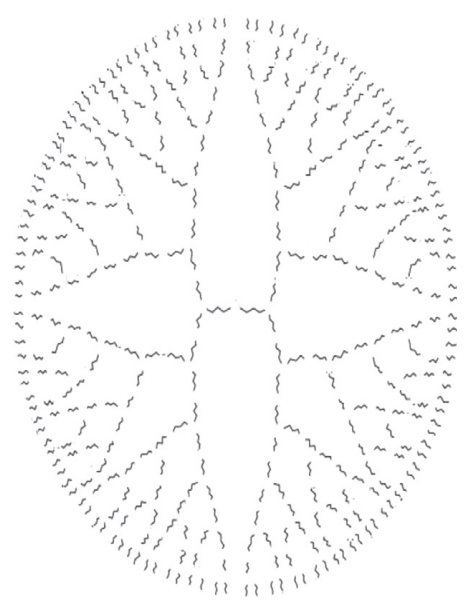

Figure 33: Propyl ether imine dendrimer (PETIM).

TABle 8: Degree-based edge partition of (PETIM).

\begin{tabular}{lc}
\hline$\left(d_{u}, d_{v}\right)$ & Frequency \\
\hline$(1,2)$ & $2^{n+1}$ \\
$(2,2)$ & $2^{n+4}-18$ \\
$(2,3)$ & $6.2^{n}-6$ \\
\hline
\end{tabular}

$$
\begin{aligned}
\operatorname{HGO}_{1}(G)= & \sum_{u v \in E(G)}\left[\left(d_{u}+d_{v}\right)+\left(d_{u} \cdot d_{v}\right)\right]^{2} \\
= & {[(1+2)+(1 \times 2)]^{2}\left(2^{n+1}\right) } \\
& +[(2+2)+(2 \times 2)]^{2}\left(2^{n+4}-18\right) \\
& +[(2+3)+(2 \times 3)]^{2}\left(6.2^{n}-6\right) \\
= & 726.2^{n}+25 . n^{n+1}+64.2^{n+4}-2120 .
\end{aligned}
$$

(2) The second hyper-Gourava index for PETIM is

$$
\begin{aligned}
\mathrm{HGO}_{2}(G)= & \sum_{u v \in E(G)}\left[\left(d_{u}+d_{v}\right) \cdot\left(d_{u} \cdot d_{v}\right)\right]^{2} \\
= & {[(1+2) \times(1 \times 2)]^{2}\left(2^{n+1}\right) } \\
& +[(2+2) \times(2 \times 2)]^{2}\left(2^{n+4}-18\right) \\
& +[(2+3) \times(2 \times 3)]^{\left(6.2^{n}-6\right)} \\
= & 5400.2^{n}+36 . n^{n+1}+256.2^{n+4}-11808 .
\end{aligned}
$$

3.4.3. Zinc-Porphyrin Dendrimer $D P Z_{n}$. The algebraic graph of zinc-porphyrin dendrimer $\mathrm{DPZ}_{n}$ is shown in Figure 34 . There are six type of edges in the edge set of porphyrin dendrimer, based on the degree of end vertices. Degree-based partition of edges of zinc-porphyrin dendrimer $\mathrm{DPZ}_{n}$ is given in Table 9. 


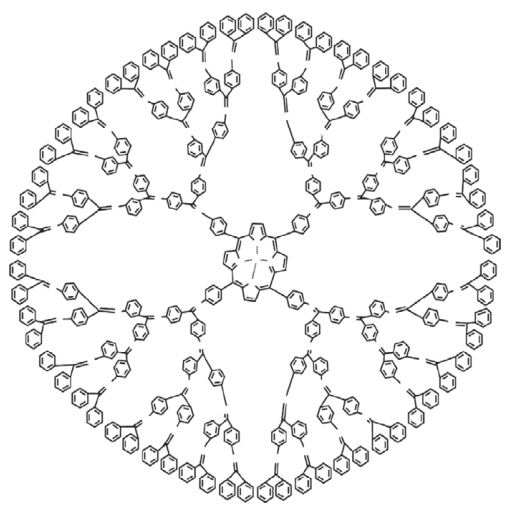

FIGURE 34: Zinc-porphyrin dendrimer $\mathrm{DPZ}_{n}$.

TABle 9: Degree-based edge partition of $\mathrm{DPZ}_{n}$.

\begin{tabular}{lc}
\hline$\left(d_{u}, d_{v}\right)$ & Frequency \\
\hline$(2,2)$ & $16.2^{n}-4$ \\
$(2,3)$ & $40.2^{n}-16$ \\
$(3,3)$ & $8.2^{n}-16$ \\
$(3,4)$ & 4 \\
\hline
\end{tabular}

Theorem 17. Let $G$ be the graph of zinc-porphyrin dendrimer $D P Z_{n}$. Then, the first and second Gourava indices are

(1) $G O_{1}(G)=688.2^{n}-372$,

(2) $\mathrm{GO}_{2}(G)=1888.2^{n}-1072$.

Proof. From the edge partition of $\mathrm{DPZ}_{n}$ given in Table 9, we have

(1) The first Gourava index for $\mathrm{DPZ}_{n}$ is

$$
\begin{aligned}
\mathrm{GO}_{1}(G)= & \sum_{u v \in E(G)}\left[\left(d_{u}+d_{v}\right)+\left(d_{u} \cdot d_{v}\right)\right] \\
= & {[(2+2)+(2 \times 2)]\left(16.2^{n}-4\right) } \\
& +[(2+3)+(2 \times 3)]\left(40.2^{n}-16\right) \\
& +[(3+3)+(3 \times 3)]\left(8.2^{n}-16\right) \\
& +[(3+4)+(3 \times 4)](4) \\
= & 688.2^{n}-372 .
\end{aligned}
$$

(2) The second Gourava index for $\mathrm{DPZ}_{n}$ is

$$
\begin{aligned}
\mathrm{GO}_{2}(G)= & \sum_{u v \in E(G)}\left[\left(d_{u}+d_{v}\right) \cdot\left(d_{u} \cdot d_{v}\right)\right] \\
= & {[(2+2) \times(2 \times 2)]\left(16.2^{n}-4\right) } \\
& +[(2+3) \times(2 \times 3)]\left(40.2^{n}-16\right) \\
& +[(3+3) \times(3 \times 3)]\left(8.2^{n}-16\right) \\
& +[(3+4) \times(3 \times 4)](4) \\
= & 1888.2^{n}-1072 .
\end{aligned}
$$

Theorem 18. Let $G$ be the graph of zinc-porphyrin dendrimer $D P Z_{n}$. Then, the first and second hyper-Gourava indices are

(1) $\mathrm{HGO}_{1}(\mathrm{G})=7664 n^{n}-5716$,

(2) $\mathrm{HGO}_{2}(G)=63424.2^{n}-33856$.

Proof. From the edge partition of $\mathrm{DPZ}_{n}$ given in Table 9, we have

(1) The first hyper-Gourava index for $\mathrm{DPZ}_{n}$ is

$$
\begin{aligned}
\mathrm{HGO}_{1}(G)= & \sum_{u v \in E(G)}\left[\left(d_{u}+d_{v}\right)+\left(d_{u} \cdot d_{v}\right)\right]^{2} \\
= & {[(2+2)+(2 \times 2)]^{2}\left(16.2^{n}-4\right) } \\
& +[(2+3)+(2 \times 3)]^{2}\left(40.2^{n}-16\right) \\
& +[(3+3)+(3 \times 3)]^{2}\left(8.2^{n}-16\right) \\
& +[(3+4)+(3 \times 4)]^{2}(4) \\
= & 7664 n^{n}-5716 .
\end{aligned}
$$

(2) The second hyper-Gourava index for $\mathrm{DPZ}_{n}$ is

$$
\begin{aligned}
\mathrm{HGO}_{2}(G)= & \sum_{u v \in E(G)}\left[\left(d_{u}+d_{v}\right) \cdot\left(d_{u} \cdot d_{v}\right)\right]^{2} \\
= & {[(2+2) \times(2 \times 2)]^{2}\left(16.2^{n}-4\right) } \\
& +[(2+3) \times(2 \times 3)]^{2}\left(40.2^{n}-16\right) \\
& +[(3+3) \times(3 \times 3)]^{2}\left(8.2^{n}-16\right) \\
& +[(3+4) \times(3 \times 4)]^{2}(4) \\
= & 63424.2^{n}-33856 .
\end{aligned}
$$

3.4.4. Poly(EThyleneAmidoAmine) Dendrimer (PETAA). The algebraic graph of Poly(EThyleneAmidoAmine) dendrimer (PETAA) is shown in Figure 35. For Poly(EThyleneAmidoAmine) dendrimer (PETAA), $\mid V($ PETAA) $) \mid=44.2^{n}-18$ and $\mid E($ PETAA $) \mid=44.2^{n}-19$. There are six type of edges in the edge set of porphyrin dendrimer, based on the degree of end vertices. Degree-based partition of edges of Poly(EThyleneAmidoAmine) dendrimer (PETAA) is given in Table 10.

Theorem 19. Let $G$ be the graph of Poly(EThylene Amide Amine) dendrimer (PETAA). Then, the first and second Gourava indices are

(1) $G O_{1}(G)=369.2^{n}-177$,

(2) $\mathrm{GO}_{2}(G)=928.2^{n}-422$.

Proof. From the edge partition of PETAA given in Table 10, we have

(1) The first Gourava index for PETAA is 


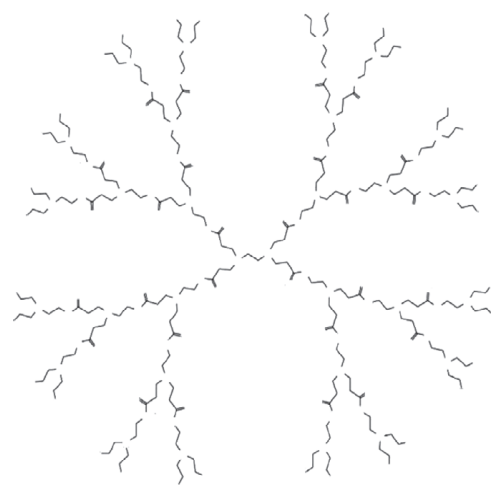

Figure 35: Poly(EThylene amide amine) dendrimer (PETAA).

TABle 10: Degree-based edge partition of (PETAA).

\begin{tabular}{lc}
\hline$\left(d_{u}, d_{v}\right)$ & Frequency \\
\hline$(1,2)$ & $4.2^{n}$ \\
$(1,3)$ & $4.2^{n}-2$ \\
$(2,2)$ & $16.2^{n}-8$ \\
$(2,3)$ & $20.2^{n}-9$ \\
\hline
\end{tabular}

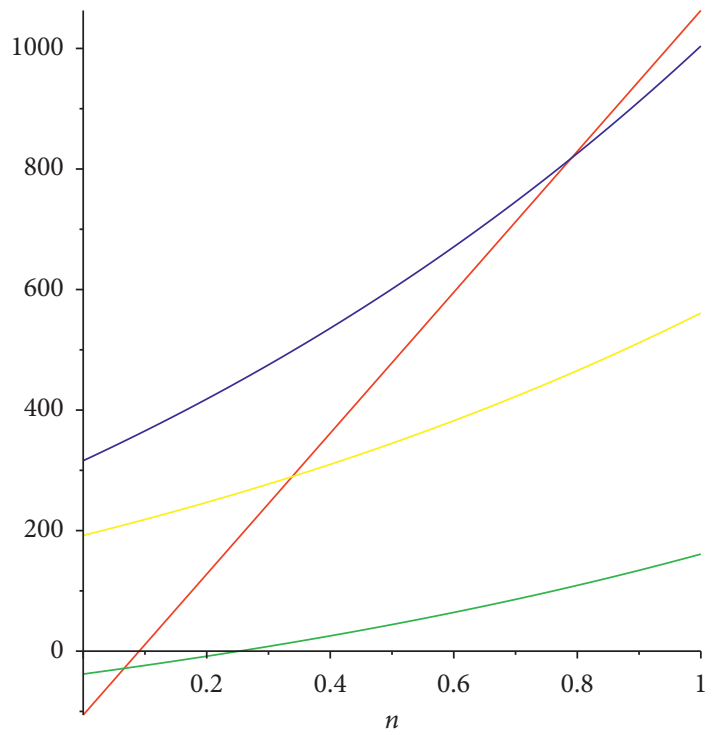

FIGURE 36: First Gourava index.

$$
\begin{aligned}
\mathrm{GO}_{1}(G)= & \sum_{u v \in E(G)}\left[\left(d_{u}+d_{v}\right)+\left(d_{u} \cdot d_{v}\right)\right] \\
= & {[(1+2)+(1 \times 2)]\left(4.2^{n}\right) } \\
& +[(1+3)+(1 \times 3)]\left(4.2^{n}-2\right) \\
& +[(2+2)+(2 \times 2)]\left(16.2^{n}-8\right) \\
& +[(2+3)+(2 \times 3)]\left(20.2^{n}-9\right) \\
= & 369.2^{n}-177 .
\end{aligned}
$$

(2) The second Gourava index for PETAA is

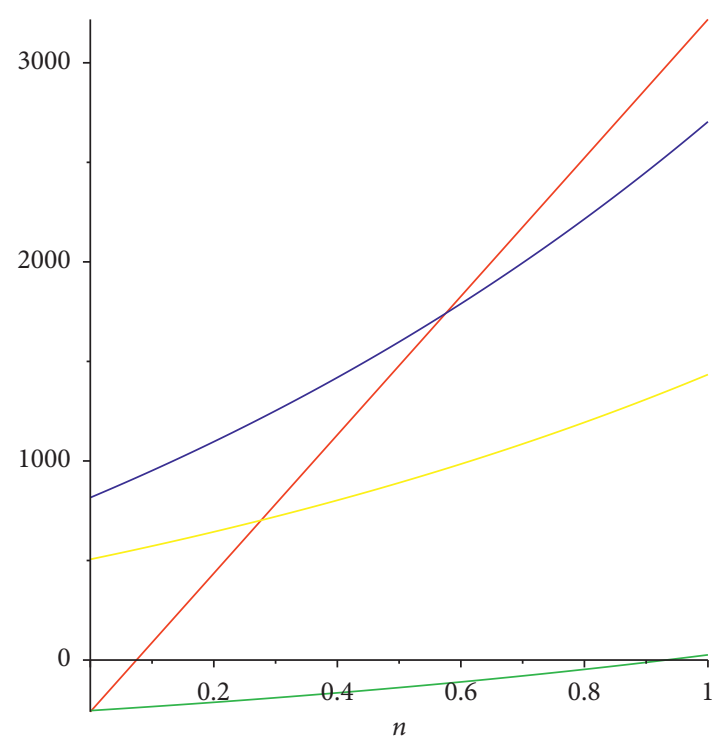

Figure 37: Second Gourava index.

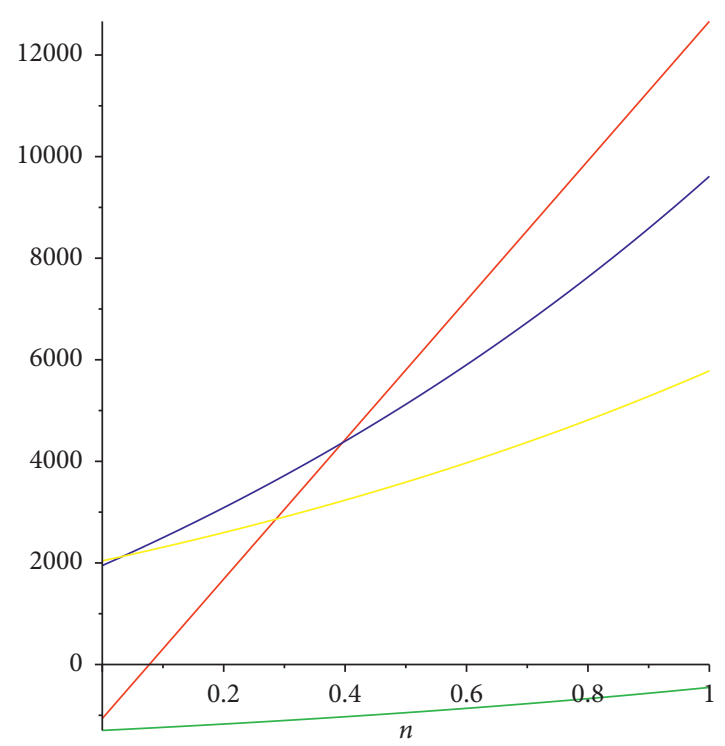

FIGURE 38: First hyper-Gourava index.

$$
\begin{aligned}
\mathrm{GO}_{2}(\mathrm{PETAA})= & \sum_{u v \in E(G)}\left[\left(d_{u}+d_{v}\right) \cdot\left(d_{u} \cdot d_{v}\right)\right] \\
= & {[(1+2) \times(1 \times 2)]\left(4.2^{n}\right) } \\
& +[(1+3) \times(1 \times 3)]\left(4.2^{n}-2\right) \\
& +[(2+2) \times(2 \times 2)]\left(16.2^{n}-8\right) \\
& +[(2+3) \times(2 \times 3)]\left(20.2^{n}-9\right) \\
= & 928.2^{n}-422 .
\end{aligned}
$$

Theorem 20. Let $G$ be the graph of Poly(EThylene Amide Amine) dendrimer (PETAA). Then, the first and second hyper-Gourava indices are 


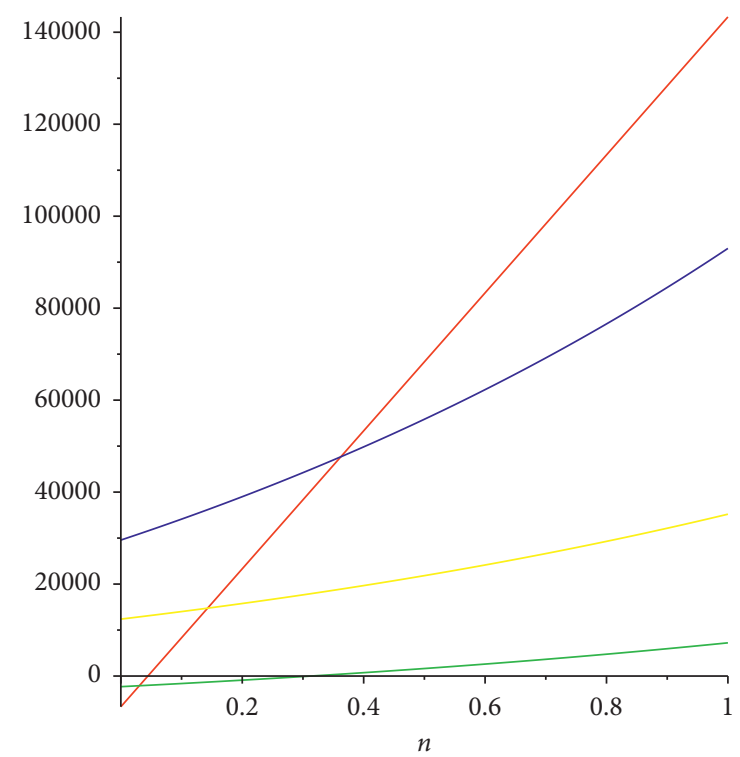

Figure 39: Second hyper-Gourava index.

(1) $\mathrm{HGO}_{1}(G)=3740.2^{n}-1699$,

(2) $\mathrm{HGO}_{2}(G)=22816.2^{n}-10436$.

Proof. From the edge partition of PETAA given in Table 10, we have

(1) The first hyper-Gourava index for PETAA is

$$
\begin{aligned}
\mathrm{HGO}_{1}(G)= & \sum_{u v \in E(G)}\left[\left(d_{u}+d_{v}\right)+\left(d_{u} \cdot d_{v}\right)\right]^{2} \\
= & {[(1+2)+(1 \times 2)]^{2}\left(4.2^{n}\right) } \\
& +\left[(1+3)+(1 \times 3)^{2}\left(4.2^{n}-2\right)\right. \\
& +[(2+2)+(2 \times 2)]^{2}\left(16.2^{n}-8\right) \\
& +[(2+3)+(2 \times 3)]^{2}\left(20.2^{n}-9\right) \\
= & 3740.2^{n}-1699 .
\end{aligned}
$$

(2) The second hyper-Gourava index for PETAA is

$$
\begin{aligned}
\mathrm{HGO}_{2}(G)= & \sum_{u v \in E(G)}\left[\left(d_{u}+d_{v}\right) \cdot\left(d_{u} \cdot d_{v}\right)\right]^{2} \\
= & {[(1+2) \times(1 \times 2)]^{2}\left(4.2^{n}\right) } \\
& +[(1+3) \times(1 \times 3)]^{2}\left(4.2^{n}-2\right) \\
& +[(2+2) \times(2 \times 2)]^{2}\left(16.2^{n}-8\right) \\
& +[(2+3) \times(2 \times 3)]^{2}\left(20.2^{n}-9\right) \\
= & 22816.2^{n}-10436 .
\end{aligned}
$$

3.4.5. Graphical Comparison. In this section, we will present the graphical comparison of first, second, first hyper-, and second hyper-Gourava indices for porphyrin dendrimer $\mathrm{D}_{n} \mathrm{P}_{n}$, propyl ether imine dendrimer (PETIM), zinc-porphyrin dendrimer $\mathrm{DPZ}_{n}$ and Poly(EThyleneAmidoAmine) dendrimer (PETAA). Figures 36-39 show the all indices are linearly increasing with respect to involved parameters.

\section{Conclusions and Future Works}

It is important to calculate topological indices of dendrimers because it is a proved fact that topological indices help to predict many properties without going to the wet lab. There are more than around 148 topological indices, but none of them can completely describe all properties of a chemical compound. Therefore, there is always room to define and study new topological indices. Gourava indices are one step in this direction and are very close to Zagreb indices. Zagreb indices are very well studied by chemists and mathematicians due to their huge applications in chemistry. It is an interesting problem for researchers to study chemical properties and bonds of Gourava indices.

\section{Data Availability}

The data used to support the findings of this study are included within the article.

\section{Conflicts of Interest}

The authors of this paper declare that they have no conflicts of interest.

\section{Authors' Contributions}

All authors have equal contribution.

\section{Acknowledgments}

This paper was supported by the Educational Commission of Anhui Province of China, under Grant no. KJ2017A627, Quality Engineering Project of Anhui Province, under Grant no. 2016sxzx021, and Quality Engineering Project of Anhui Xinhua University, under Grant nos. 2015xqjdx04; 2015xxk06; AH20171221607.

\section{References}

[1] M. Munir, W. Nazeer, S. Rafique, and S. Kang, "M-polynomial and related topological indices of Nanostar dendrimers," Symmetry, vol. 8, no. 9, p. 97, 2016.

[2] M. Munir, W. Nazeer, A. Nizami, S. Rafique, and S. Kang, "Mpolynomials and topological indices of titania nanotubes," Symmetry, vol. 8, no. 11, p. 117, 2016.

[3] Y. Kwun, M. Munir, W. Nazeer, S. Rafique, and S. M. Kang, "M-polynomial and degree-based topological indices of V-phenalinic nanotubes and nanotori," Scientific Reports, vol. 7, no. 1, p. 8756, 2017.

[4] M. Munir, W. Nazeer, S. Rafique, A. Nizami, and S. Kang, "Some computational aspects of boron triangular nanotubes," Symmetry, vol. 9, no. 1, p. 6, 2016.

[5] M. Munir, W. Nazeer, S. Rafique, and S. Kang, "M-polynomial and degree-based topological indices of polyhex nanotubes," Symmetry, vol. 8, no. 12, p. 149, 2016. 
[6] M. Imran, M. Siddiqui, M. Naeem, and M. Iqbal, "On topological properties of symmetric chemical structures," Symmetry, vol. 10, no. 5, p. 173, 2018.

[7] M. Alaeiyan, M. R. Farahani, and M. K. Jamil, "Computation of the fifth geometric-arithmetic index for polycyclic aromatic hydrocarbons pahk," Applied Mathematics and Nonlinear Sciences, vol. 1, no. 1, pp. 283-290, 2016.

[8] M. K. Jamil, M. R. Farahani, M. Imran, and M. Ali Malik, "Computing eccentric version of second zagreb index of polycyclic aromatic hydrocarbons (PAHk)," Applied Mathematics and Nonlinear Sciences, vol. 1, no. 1, pp. 247-252, 2016.

[9] M. R. Farahani, M. K. Jamil, and M. Imran, "Vertex PIv topological index of titania carbon nanotubes $\mathrm{TiO}_{2}(m, n)$," Applied Mathematics and Nonlinear Sciences, vol. 1, no. 1, pp. 175-182, 2016.

[10] G. Rücker and C. Rücker, "On topological indices, boiling points, and cycloalkanes," Journal of Chemical Information and Computer Sciences, vol. 39, no. 5, pp. 788-802, 1999.

[11] S. Klavžar and I. Gutman, "A comparison of the Schultz molecular topological index with the Wiener index," Journal of Chemical Information and Computer Sciences, vol. 36, no. 5, pp. 1001-1003, 1996.

[12] F. M. Brückler, T. Došlić, A. Graovac, and I. Gutman, "On a class of distance-based molecular structure descriptors," Chemical Physics Letters, vol. 503, no. 4-6, pp. 336-338, 2011.

[13] H. Deng, J. Yang, and F. Xia, "A general modeling of some vertex-degree based topological indices in benzenoid systems and phenylenes," Computers \& Mathematics with Applications, vol. 61, no. 10, pp. 3017-3023, 2011.

[14] H. Zhang and F. Zhang, "The Clar covering polynomial of hexagonal systems I," Discrete Applied Mathematics, vol. 69, no. 1-2, pp. 147-167, 1996.

[15] H. Wiener, "Structural determination of paraffin boiling points," Journal of the American Chemical Society, vol. 69, no. 1, pp. 17-20, 1947.

[16] A. A. Dobrynin, R. Entringer, and I. Gutman, "Wiener index of trees: theory and applications," Acta Applicandae Mathematicae, vol. 66, no. 3, pp. 211-249, 2001.

[17] A. A. Dobrynin, I. Gutman, S. Klavžar, and P. Žigert, "Wiener index of hexagonal systems," Acta Applicandae Mathematicae, vol. 72, no. 3, pp. 247-294, 2002.

[18] W. Gao and L. Shi, "Wiener index of gear fan graph and gear wheel graph," Asian Journal of Chemistry, vol. 26, no. 11, 2014.

[19] W. F. Xi and W. Gao, " $\lambda$-modified extremal hyper-Wiener index of molecular graphs," Journal of Applied Computer Science \& Mathematics, vol. 18, no. 8, pp. 43-46, 2014.

[20] W. Gao and W. Wang, "The vertex version of weighted Wiener number for bicyclic molecular structures," Computational and Mathematical Methods in Medicine, vol. 2015, Article ID 418106, 10 pages, 2015.

[21] M. Randic, "Characterization of molecular branching," Journal of the American Chemical Society, vol. 97, no. 23, pp. 6609-6615, 1975.

[22] M. Randic, "On history of the Randic index and emerging hostility toward chemical graph theory," MATCH Communications in Mathematical and in Computer Chemistry, vol. 59, pp. 5-124, 2008.

[23] X. Li and Y. Shi, "A survey on the Randic index," MATCH Communications in Mathematical and in Computer Chemistry, vol. 59, no. 1, pp. 127-156, 2008.

[24] S. B. Bozkurt, A. D. Gungor, I. Gutman, and A. S. Cevik, "Randic matrix and Randic energy," MATCH Communications in Mathematical and in Computer Chemistry, vol. 64, pp. 239-250, 2010.
[25] C. Delorme, O. Favaron, and D. Rautenbach, "On the Randić index,” Discrete Mathematics, vol. 257, no. 1, pp. 29-38, 2002.

[26] Y. Hu, X. Li, Y. Shi, T. Xu, and I. Gutman, "On molecular graphs with smallest and greatest zeroth-order general Randic index," MATCH Communications in Mathematical and in Computer Chemistry, vol. 54, no. 2, pp. 425-434, 2005.

[27] M. Cavers, S. Fallat, and S. Kirkland, "On the normalized Laplacian energy and general Randić index," Linear Algebra and Its Applications, vol. 433, no. 1, pp. 172-190, 2010.

[28] I. Gutman and N. Trinajstic, "Graph theory and molecular orbitals. Total $\pi$-electron energy of alternant hydrocarbons," Chemical Physics Letters, vol. 17, no. 4, pp. 535-538, 1972.

[29] B. Zhou and I. Gutman, "Further properties of Zagreb indices," MATCH Communications in Mathematical and in Computer Chemistry, vol. 54, no. 1, pp. 233-239, 2005.

[30] I. Gutman, B. Furtula, Z. K. Vukicevic, and G. Popivoda, "On Zagreb indices and coindices," MATCH Communications in Mathematical and in Computer Chemistry, vol. 74, no. 1, pp. 5-16, 2015.

[31] I. Gutman, "Multiplicative Zagreb indices of trees," Bulletin of Society of Mathematicians Banja Luka, vol. 18, pp. 17-23, 2011.

[32] B. Zhou and I. Gutman, "Relations between wiener, hyperwiener and zagreb indices," Chemical Physics Letters, vol. 394, no. 1-3, pp. 93-95, 2004.

[33] I. Gutman, "An exceptional property of first Zagreb index," MATCH Communications in Mathematical and in Computer Chemistry, vol. 72, no. 3, pp. 733-740, 2014.

[34] W. Gao, M. R. Farahani, and L. Shi, "Forgotten topological index of some drug structures," Acta Medica Mediterranea, vol. 32, no. 1, pp. 579-585, 2016.

[35] W. Gao, M. K. Siddiqui, M. Imran, M. K. Jamil, and M. R. Farahani, "Forgotten topological index of chemical structure in drugs," Saudi Pharmaceutical Journal, vol. 24, no. 3, pp. 258-264, 2016.

[36] W. Gao, W. Wang, and M. R. Farahani, "Topological indices study of molecular structure in anticancer drugs," Journal of Chemistry, vol. 2016, Article ID 3216327, 8 pages, 2016.

[37] W. Gao, Y. Wang, W. Wang, and L. Shi, "The first multiplication atom-bond connectivity index of molecular structures in drugs," Saudi Pharmaceutical Journal, vol. 25, no. 4, pp. $548-555,2017$.

[38] S. Hayat and M. Imran, "Computation of certain topological indices of nanotubes covered by $C_{5}$ and $C_{7}$," Journal of Computational and Theoretical Nanoscience, vol. 12, no. 4, pp. 533-541, 2015.

[39] S. Hayat and M. Imran, "Computation of topological indices of certain networks," Applied Mathematics and Computation, vol. 240, pp. 213-228, 2014.

[40] W. Gao, M. Siddiqui, M. Naeem, and N. Rehman, “Topological characterization of carbon graphite and crystal cubic carbon structures," Molecules, vol. 22, no. 9, p. 1496, 2017.

[41] M. Imran, M. Siddiqui, A. Abunamous, D. Adi, S. Rafique, and A. Baig, "Eccentricity based topological indices of an oxide network," Mathematics, vol. 6, no. 7, p. 126, 2018.

[42] Y. Kwun, A. Virk, W. Nazeer, M. Rehman, and S. Kang, "On the multiplicative degree-based topological indices of siliconcarbon $\mathrm{Si}_{2} \mathrm{C}_{3}-\mathrm{I}[p, q]$ and $\mathrm{Si}_{2} \mathrm{C}_{3}-\mathrm{II}[p, q]$," Symmetry, vol. 10, no. 8, p. 320, 2018.

[43] W. Gao, M. Younas, A. Farooq, A. Mahboob, and W. Nazeer, "M-polynomials and degree-based topological indices of the crystallographic structure of molecules," Biomolecules, vol. 8, no. 4, p. 107, 2018. 
[44] V. R. Kulli, "The Gourava indices and coindices of graphs," Annals of Pure and Applied Mathematics, vol. 14, no. 1, pp. 33-38, 2017.

[45] V. R. Kulli, "Computation of some Gourava indices of titania nanotubes," International Journal of Fuzzy Mathematical Archive, vol. 12, no. 2, pp. 75-81, 2017.

[46] M. Imran, M. A. Ali, S. Ahmad, M. K. Siddiqui, and A. Q. Baig, "Topological characterization of the symmetrical structure of bismuth tri-iodide," Symmetry, vol. 10, no. 6, p. 201, 2018.

[47] B. Iodide, McGraw-Hill Dictionary of Scientific and Technical Terms, McGraw-Hill, New York, NY, USA, 2003.

[48] R. A. Mackay and W. Henderson, Introduction to Modern Inorganic Chemistry, CRC Press, Boca Raton, FL, USA, 2002.

[49] L. Smart and A. M. Elaine, Solid State Chemistry: An Introduction, CRC Press, Boca Raton, FL, USA, 2005.

[50] K. Watanabe, T. Karasawa, T. Komatsu, and Y. Kaifu, "Optical properties of extrinsic two-dimensional excitons in $\mathrm{BiI}_{3}$ single crystals," Journal of the Physical Society of Japan, vol. 55, no. 3, pp. 897-907, 1986.

[51] R. W. G. Wyckoff, Crystal Structures, John Wiley \& Sons, Inc., New York, NY, USA, 2nd edition, 1964.

[52] H. Yorikawa and S. Muramatsu, "Theoretical study of crystal and electronic structures of $\mathrm{BiI}_{3}$," Journal of Physics: Condensed Matter, vol. 20, pp. 325-335, 2008.

[53] M. Imran, M. Siddiqui, A. Ahmad, U. Ali, and N. Hanif, "On the degree-based topological indices of the Tickysim SpiNNaker model," Axioms, vol. 7, no. 4, p. 73, 2018.

[54] S. Imran, M. Siddiqui, M. Imran, and M. Nadeem, "Computing topological indices and polynomials for line graphs," Mathematics, vol. 6, no. 8, p. 137, 2018.

[55] Z. Shao, M. Siddiqui, and M. Muhammad, "Computing zagreb indices and zagreb polynomials for symmetrical nanotubes," Symmetry, vol. 10, no. 7, p. 244, 2018.

[56] J. B. Liu, M. Siddiqui, M. Zahid, M. Naeem, and A. Baig, "Topological properties of crystallographic structure of molecules," Symmetry, vol. 10, no. 7, p. 265, 2018.

[57] W. Gao, M. Younas, A. Farooq, A. Virk, and W. Nazeer, "Some reverse degree-based topological indices and polynomials of dendrimers," Mathematics, vol. 6, no. 10, p. 214 , 2018.

[58] Z. Hussain, M. Munir, S. Rafique, and S. Min Kang, "Topological characterizations and index-analysis of new degreebased descriptors of honeycomb networks," Symmetry, vol. 10, no. 10, p. 478, 2018.

[59] M. Salaheldeen Abdelgader, C. Wang, and S. Abdalrhman Mohammed, "Computation of topological indices of some special graphs," Mathematics, vol. 6, no. 3, p. 33, 2018.

[60] X. Zhang, M. Siddiqui, M. Naeem, and A. Baig, "Computing eccentricity based topological indices of octagonal grid $\mathrm{O}$ nm," Mathematics, vol. 6, no. 9, p. 153, 2018.

[61] J. B. Liu, H. Ali, M. Shafiq, and U. Munir, "On degree-based topological indices of symmetric chemical structures," Symmetry, vol. 10, no. 11, p. 619, 2018.

[62] W. Nazeer, A. Farooq, M. Younas, M. Munir, and S. Kang, "On molecular descriptors of carbon nanocones," Biomolecules, vol. 8, no. 3, p. 92, 2018.

[63] M. Zahid, A. Baig, M. Naeem, and M. Azhar, "Eccentricitybased topological indices of a cyclic octahedron structure," Mathematics, vol. 6, no. 8, p. 141, 2018.

[64] H. Yang, M. Siddiqui, M. Arshad, and M. Naeem, "Degreedistance based topological indices of crystal cubic carbon structure," Atoms, vol. 6, no. 4, p. 62, 2018.
[65] Z. Shao, Pu Wu, X. Zhang, D. Dimitrov, and J.-B. Liu, "On the maximum $\mathrm{ABC}$ index of graphs with prescribed size and without pendent vertices," IEEE Access, vol. 6, pp. 2760427616, 2018.

[66] Z. Shao, Pu Wu, Y. Gao, I. Gutman, and X. Zhang, "On the maximum ABC index of graphs without pendent vertices," Applied Mathematics and Computation, vol. 315, pp. 298-312, 2017. 